\title{
New groundwater-level rise data from the Rhine-Meuse delta - implications for the reconstruction of Holocene relative mean sea-level rise and differential land-level movements
}

\author{
H.J.A. Berendsen ${ }^{1, \dagger}$, B. Makaske ${ }^{2,}{ }^{*}, 0$. van de Plassche ${ }^{3}$, M.H.M. van Ree ${ }^{1}$, S. Das ${ }^{1}$, \\ M. van Dongen ${ }^{1}$, S. Ploumen ${ }^{1} \&$ W. Schoenmakers ${ }^{1}$
}

1 Faculty of Geosciences, Department of Physical Geography, Utrecht University, Heidelberglaan 2, 3534 CS Utrecht, the Netherlands.

2 Faculty of Geosciences, Department of Physical Geography, Utrecht University, the Netherlands; now at: Alterra, Wageningen University and Research Centre, P.0. Box 47, 6700 AA Wageningen, the Netherlands.

3 Faculty of Earth and Life Sciences, VU University Amsterdam, De Boelelaan 1085, 1081 HV Amsterdam, the Netherlands.

* Corresponding author. Email: bart.makaske@wur.nl

$\dagger$ Henk Berendsen passed away on May 14, 2007.

Manuscript received: March 2007; accepted: December 2007

\begin{abstract}
We present new local groundwater-level rise data from two Late Glacial aeolian dunes, located near Barendrecht and Oud-Alblas in the western Rhine-Meuse delta. These data are based on AMS radiocarbon dating of terrestrial macrofossils, collected from the base of peat formed on the slopes of these dunes. This method avoids contamination of bulk peat samples by old soil carbon or younger rootlets and rhizomes, as well as the hardwater effect. The new data are used to assess the reliability of previously published groundwater-level index data based on conventional radiocarbon dating of bulk basal peat samples from the slopes of the Late Glacial aeolian dunes at Barendrecht, Hillegersberg, Bolnes and Wijngaarden, all located in the western Rhine-Meuse delta.

Comparison of the new and published groundwater-level data shows no significant systematic difference between conventionally dated bulk peat samples and AMS-dated samples of terrestrial macrofossils. The new data from the dune at Barendrecht confirm the reliability of the younger than $6600 \mathrm{cal}$ yr BP age-depth data from the dunes at Hillegersberg and near Bolnes. This result supports the validity of this part of the mean sea-level (MSL) curve for the western Netherlands. Consequently, the position of the groundwater-level curve for Flevoland (central Netherlands) below this MSL curve can most likely be attributed to differential land-level movement.

The available data show that the groundwater-gradient effect in the western Rhine-Meuse delta became less than $5 \mathrm{~cm} / \mathrm{km}$ after $6600 \mathrm{cal} \mathrm{yr}$ BP. Finally, temporal correlation between temporary increases in local groundwater-level rise with known shifts of river courses in the delta plain suggests, that avulsions can explain sudden local deviations from the trend in groundwater-level rise. A general conclusion of this study is that a complex relationship exists between sea level and local delta-plain water levels.
\end{abstract}

Keywords: AMS dating, avulsions, Holocene sea-level rise, Late Glacial aeolian dunes, river-gradient effect

\section{Introduction}

Reconstructions of Holocene relative sea-level and groundwater-level rise are crucial for understanding the palaeogeographical and geological evolution of coastal plains, while also serving studies of differential land-level change, palaeoecology, and archaeology. At present, the quest for higher accuracy in sea-level reconstruction and for better understanding of differences between local groundwater-level curves is still ongoing.

Studies of Holocene relative (ground)water change and sealevel change in the Netherlands are based primarily on radiocarbon-dated samples from the base of peats which accumulated on pre-Holocene substrates (e.g., Jelgersma, 1961, 1979, 
1980; Van de Plassche, 1982, 1995; Van Dijk et al., 1991; Roeleveld \& Gotjé, 1993; Kiden, 1995; Cohen, 2003; Makaske et al., 2003; Van de Plassche et al., 2005). In many cases, basal peats from the slopes of Late Weichselian aeolian dunes were used to reconstruct local curves of groundwater-level rise. The approach of using peat as a sea-level or groundwater-level indicator has been validated by independent research methods (e.g., Roep \& Beets, 1988). Groundwater-level changes in coastal areas are a function of mean sea-level (MSL) rise, superimposed changes in regional and local tidal range and changes in regional and local river or groundwater gradient. The question is: how should spatial and temporal differences within and between groundwater-level curves be interpreted, given the accuracy and reliability of such curves?

Sea-level curves from roughly before 1990 are based on conventionally radiocarbon-dated bulk samples from (basal) peat layers. A potential drawback of such samples is that they may contain rootlets and reed rhizomes that penetrated the sample from higher stratigraphic levels, resulting in an apparent younger age (e.g., Streif, 1971). Another drawback of dating bulk peat samples is that they may yield apparent older ages due to the so-called hardwater effect (e.g., Törnqvist et al., 1992) or due to inclusion of old soil carbon (Van de Plassche, 1982). The hardwater effect originates from plants that assimilate $\mathrm{CO}_{2}$ from the water containing $\mathrm{CO}_{2}$ from dissolved old $\mathrm{CaCO}_{3}$, instead of from the atmosphere. Moreover, conventional ${ }^{14} \mathrm{C}$ dating of bulk peat samples generally requires $>10 \mathrm{~g}$ organic material from a $5-10 \mathrm{~cm}$ thick core interval, which may cover a considerable time span. This may affect the accuracy of the age the date is supposed to represent (Törnqvist et al., 1992). To avoid all of these potential problems, accelerator mass spectrometry (AMS) dating is now generally applied. This technique allows analysis of much smaller samples (<20 $\mathrm{mg}$ ) that generally cover only $\sim 1 \mathrm{~cm}$ thick core intervals and presumably results in more representative dates. Errors such as caused by the hardwater effect, the inclusion of old soil carbon or younger roots can be avoided by selecting terrestrial macrofossils instead of bulk peat.

Hitherto, only one study has been carried out in which a (ground)water-level curve based on conventional radiocarbon dating of bulk samples was tested against new AMS-dated samples of terrestrial macrofossils from the same site (Van de Plassche et al., 2005). This study was carried out in Flevoland (central Netherlands, Fig. 1) and yielded water-level index points below the mean sea-level (MSL) curve for the western Netherlands (Van de Plassche, 1982). It confirmed results reached by Roeleveld \& Gotjé (1993), which were based on conventionally dated bulk peat samples, and led to a MSL curve for Flevoland running below Van de Plassche's (1982) MSL curve, at least for the part between 6000 and $3500 \mathrm{cal}$ yr BP. Because this part of the 1982 MSL curve was based on conventionally dated bulk peat samples from the western Rhine-Meuse delta, a methodological cause (AMS macrofossil dates vs. conventional bulk dates) of the difference between the two curves was suggested, but alternative causes such as differences in tidal effects and/or land-level movements could not be excluded (Van de Plassche et al., 2005). In this paper we address the question whether previously published dates of bulk peat samples are too old due to the hardwater effect or to the inclusion of old carbon as suggested by Roeleveld and Gotjé (1993).

The aims of this paper are: (1) to evaluate and explain differences in groundwater-level rise data in the western Netherlands in terms of methodological effects, and spatial and temporal effects related to palaeogeography and evolution of the coastal plain; (2) to evaluate the cause of the difference between the curve from Flevoland (Van de Plassche et al., 2005) and the curves from the western Netherlands.

We collected two new local groundwater-level data sets on the flanks of aeolian dunes in the western part of the RhineMeuse delta. These new data sets represent AMS-dated samples of terrestrial macrofossils. We compare these new high-quality data with previously published data sets from this area, which are based on conventionally dated bulk peat samples (Jelgersma, 1961; Van de Plassche, 1982; Van Dijk et al., 1991).

\section{Approach and methods}

\section{Site characteristics and fieldwork}

Based on the geological map of the Netherlands, scale $1: 50,000$ (Verbraeck, 1974; Bosch \& Kok, 1994), we selected two buried Late Weichselian aeolian dunes in the western part of the Rhine-Meuse delta. Both dunes are (almost) completely covered by Holocene deposits: only at one of the sites (Oud-Alblas) the very top of the dune is exposed at the surface. We constructed a local groundwater-level rise curve using AMS-dated terrestrial macrofossils from the base of peat, flanking the dunes. The dunes are located near the towns of Barendrecht and OudAlblas (Fig. 1). They were selected for accessibility and presence of basal peat on their slopes over a large vertical range. Fieldwork for this study was carried out in 1995, and collected samples were subsequently analysed and dated in 1996 and 1997. Soon after the collection of samples, the Barendrecht site became inaccessible as a result of development by the city of Barendrecht. At both locations, the general topography of the dune was mapped using an Edelman-auger and a $3 \mathrm{~cm}$ wide gouge (Berendsen \& Stouthamer, 2001).

The dune at Barendrecht (Fig. 2) is $\sim 14.4 \mathrm{~m}$ high, with the top of the dune sand at $0.6 \mathrm{~m}$ below the surface (outside crosssection in Fig. 2) and the top of the underlying Kreftenheye Formation (fluvial Weichselian deposits) at a depth of $\sim 15 \mathrm{~m}$ below the surface. At Oud-Alblas (Fig. 3), the top of the dune is at $1.3 \mathrm{~m}$ below the surface in our cross-section. The base of the dune was not reached, but is at more than $10 \mathrm{~m}$ below the surface. Based on the maps, detailed cross-sections were 


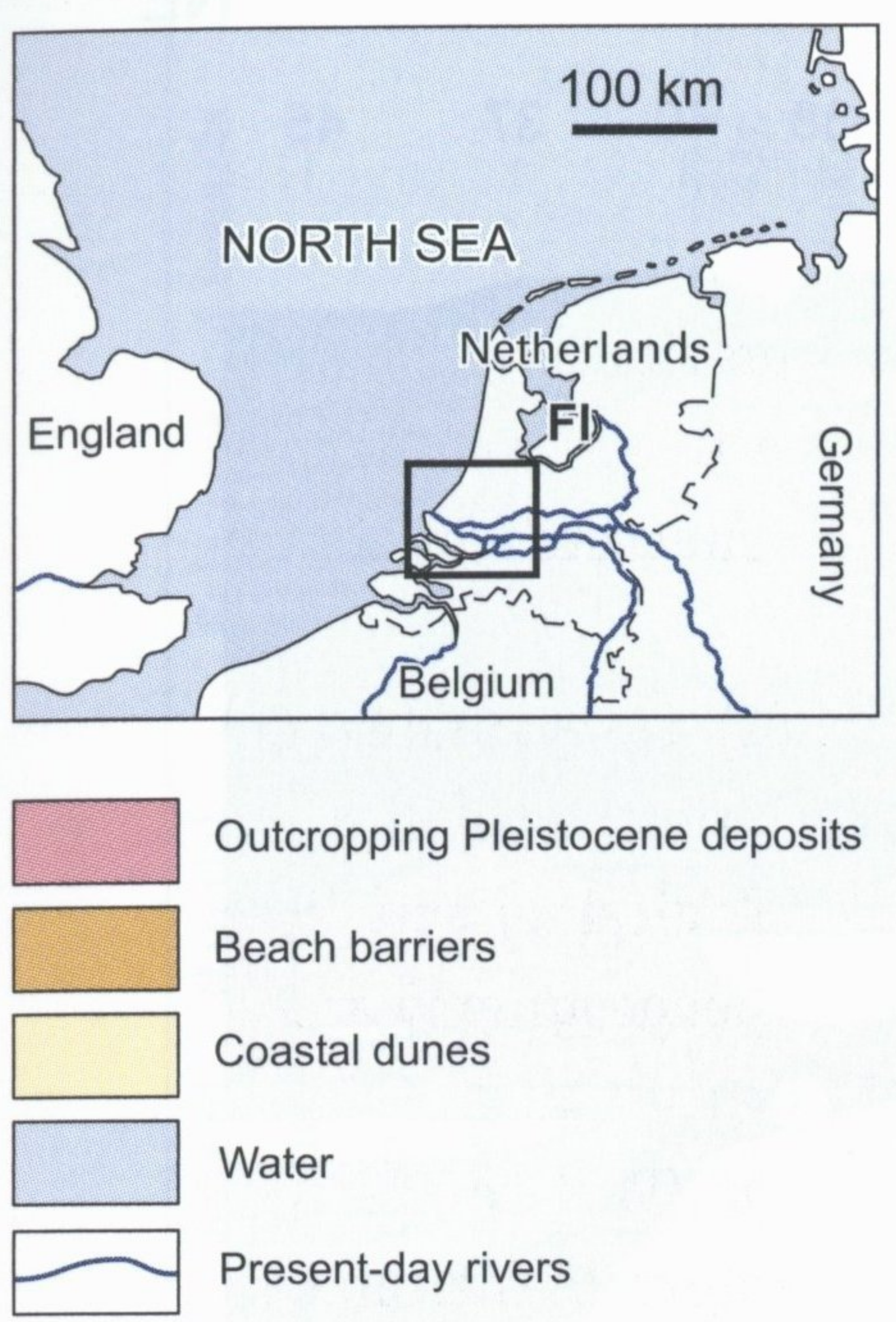

y co-ordinates

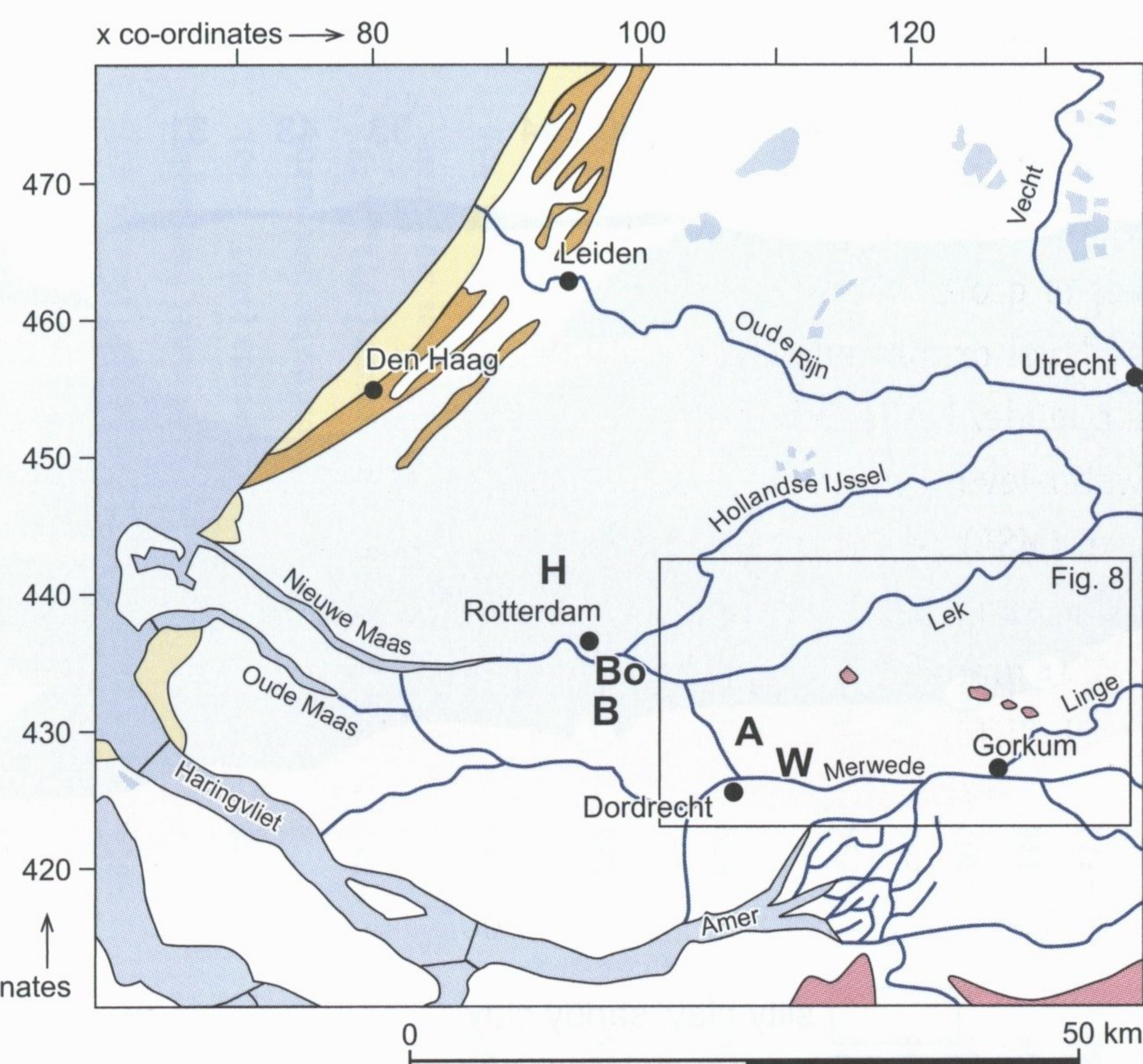

Bo Bolnes (Van de Plassche, 1982)

H Hillegersberg (Van de Plassche, 1982)

B Barendrecht (Jelgersma, 1961; and this paper, data published by Berendsen \& Stouthamer, 2001)

W Wijngaarden (Van Dijk et al., 1991)

A Oud-Alblas (this paper, data published by Berendsen \& Stouthamer, 2001)

produced at each dune, using an Edelman-auger and a gouge. The cross-sections are oriented in the direction of maximum slope; coring sites are $\sim 5 \mathrm{~m}$ apart. From these cross-sections, approximately $50 \mathrm{~cm}$ long undisturbed cores were collected at more or less regular vertical intervals (Figs 2 and 3), using a Dachnowski-sampler and a $7 \mathrm{~cm}$ wide gouge. Depressions in the dune surface were avoided as much as possible, because peat formation may have started earlier in depressions relative to better drained slopes (Van de Plassche, 1982). The cores were sub-sampled for AMS dating.

In addition to the newly collected data, the database for this paper contains published groundwater-level index data

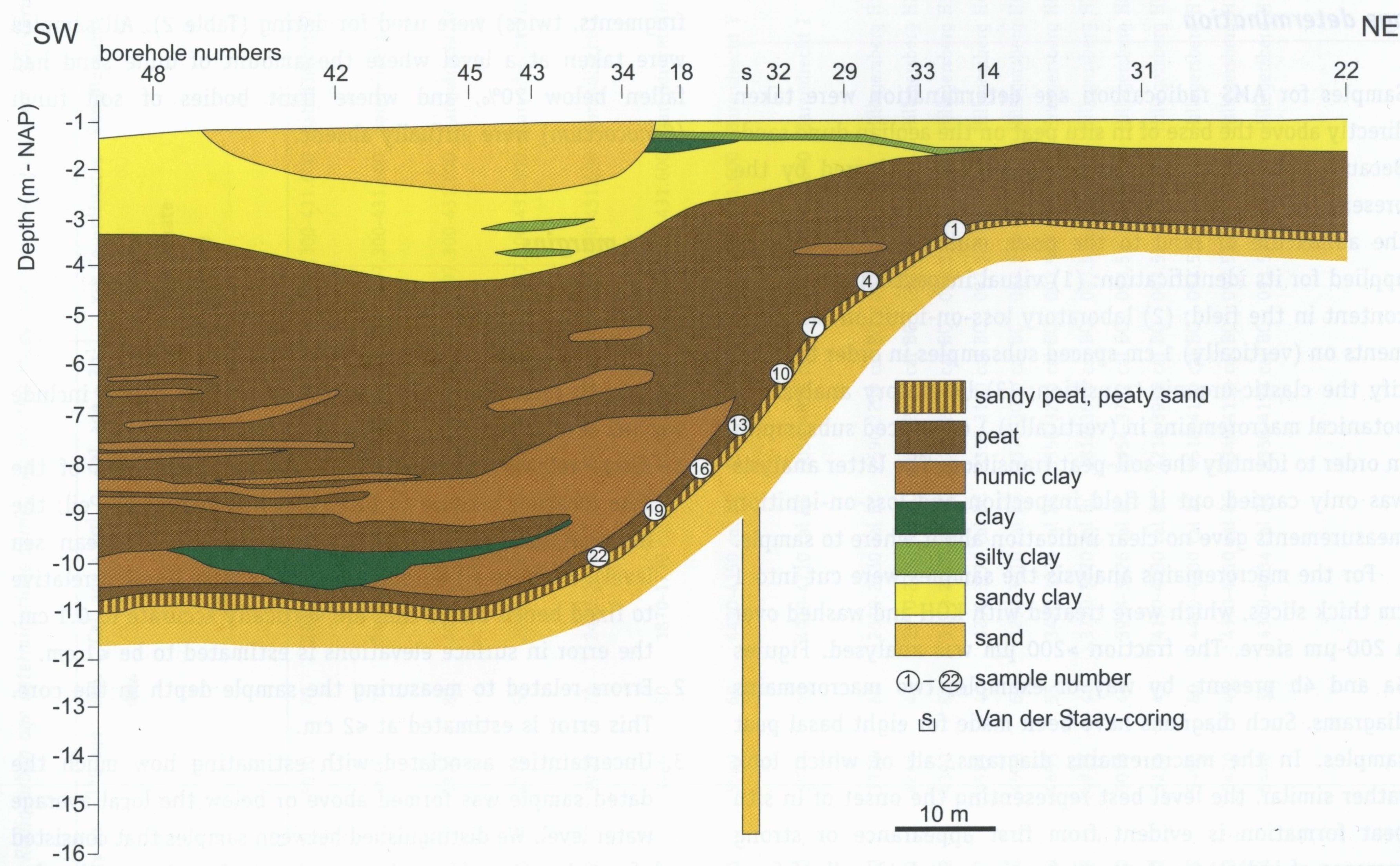

Fig. 2. Cross-section of the Barendrecht dune flank, with sample locations. Samples Barendrecht 23, 24, 26 and 27 were not collected in this cross-section. 


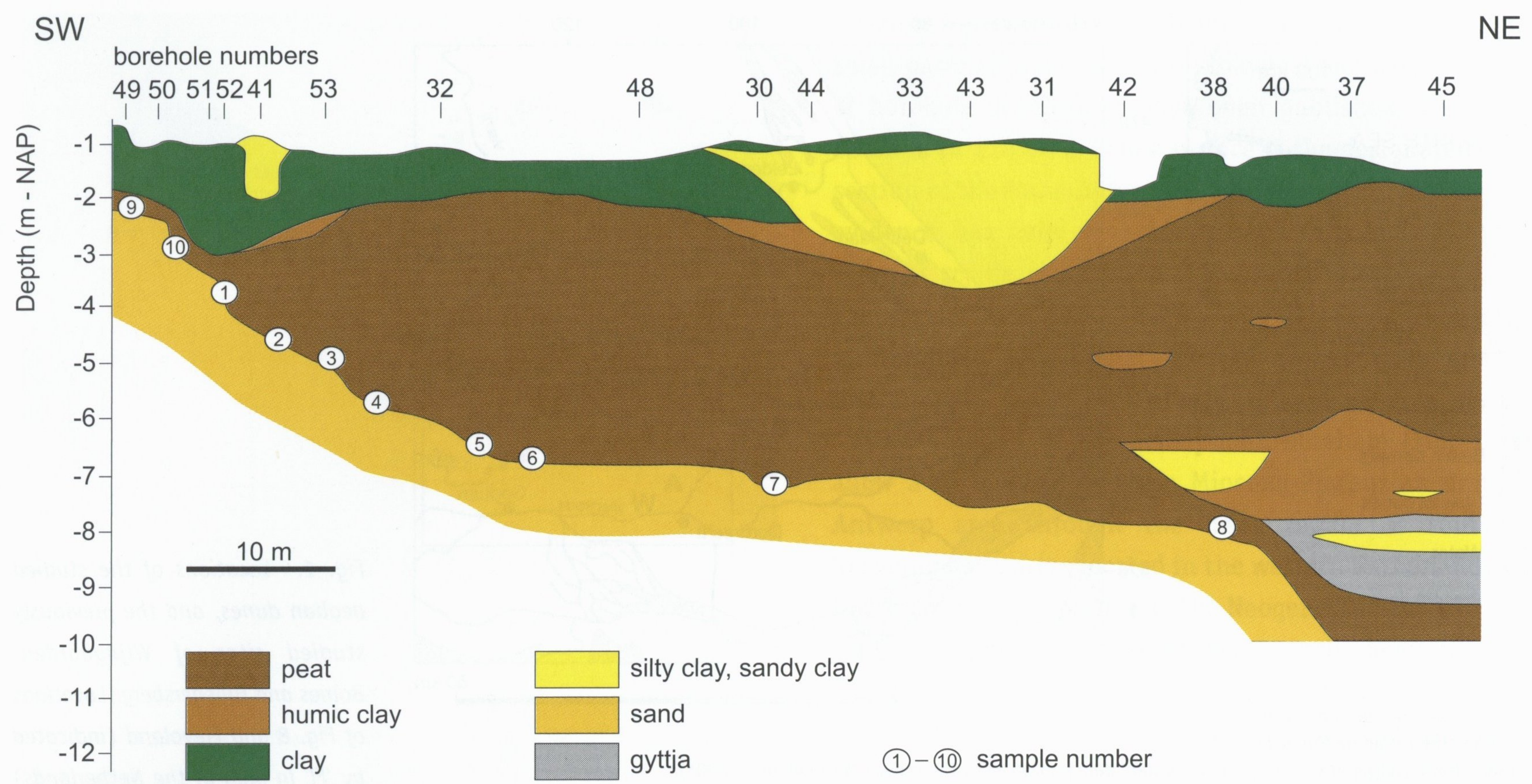

Fig. 3. Cross-section of the Oud-Alblas dune flank, with sample locations.

(conventional radiocarbon age determinations of bulk basal peat samples) for aeolian dunes at Barendrecht (Jelgersma, 1961), Bolnes and Hillegersberg (Van de Plassche, 1982), and Wijngaarden (Van Dijk et al., 1991), see Table 1, and Fig. 1 for locations.

\section{Selection of samples for AMS radiocarbon age determination}

Samples for AMS radiocarbon age determination were taken directly above the base of in situ peat on the aeolian dune sand. Because this sand-peat transition usually is blurred by the presence of a palaeosoil in the top of the aeolian sand and by the admixture of sand to the peat, multiple methods were applied for its identification: (1) visual inspection of the core content in the field; (2) laboratory loss-on-ignition measurements on (vertically) $1 \mathrm{~cm}$ spaced subsamples in order to identify the clastic-organic transition; (3) laboratory analysis of botanical macroremains in (vertically) $1 \mathrm{~cm}$ spaced subsamples in order to identify the soil-peat transition. The latter analysis was only carried out if field inspection and loss-on-ignition measurements gave no clear indication about where to sample.

For the macroremains analysis the samples were cut into 1 $\mathrm{cm}$ thick slices, which were treated with $\mathrm{KOH}$ and washed over a $200-\mu \mathrm{m}$ sieve. The fraction $>200 \mu \mathrm{m}$ was analysed. Figures $4 \mathrm{a}$ and $4 \mathrm{~b}$ present, by way of example, two macroremains diagrams. Such diagrams have been made for eight basal peat samples. In the macroremains diagrams, all of which look rather similar, the level best representing the onset of in situ peat formation is evident from first appearance or strong increase of indicators of a peat-forming vegetation (leaf fragments, bud scales, Typha, Carex, Alnus remains), together with the (near-)absence of soil fungi (Cenococcum fruit bodies) and a low $(<10 \%)$ sand content.

After identification of the optimal sampling level, we cut a $1 \mathrm{~cm}$ thick slice from the core to extract dateable macroremains. If a particular slice did not yield enough material, the next higher $1 \mathrm{~cm}$ thick slice was added to the sample, and so on, if necessary. Terrestrial macrofossils (seeds, fruits, bud scales, leaf fragments, twigs) were used for dating (Table 2). All samples were taken at a level where the amount of dune sand had fallen below $20 \%$, and where fruit bodies of soil fungi (Cenococcum) were virtually absent.

\section{Error margins}

\section{Depth-error margins}

The depth-error margins of water-level index points include various categories of errors and uncertainties.

1. Errors related to measuring the surface elevation of the core location relative to NAP: Nieuw Amsterdams Peil; the national geodetic datum, approximately MSL (mean sea level). Because all borehole locations were levelled relative to fixed bench marks that are vertically accurate to $0.1 \mathrm{~cm}$, the error in surface elevations is estimated to be $\leqslant 1 \mathrm{~cm}$.

2. Errors related to measuring the sample depth in the core. This error is estimated at $\leqslant 2 \mathrm{~cm}$.

3. Uncertainties associated with estimating how much the dated sample was formed above or below the local average water level. We distinguished between samples that consisted of wood peat and samples composed of reed or reed-sedge peat. 


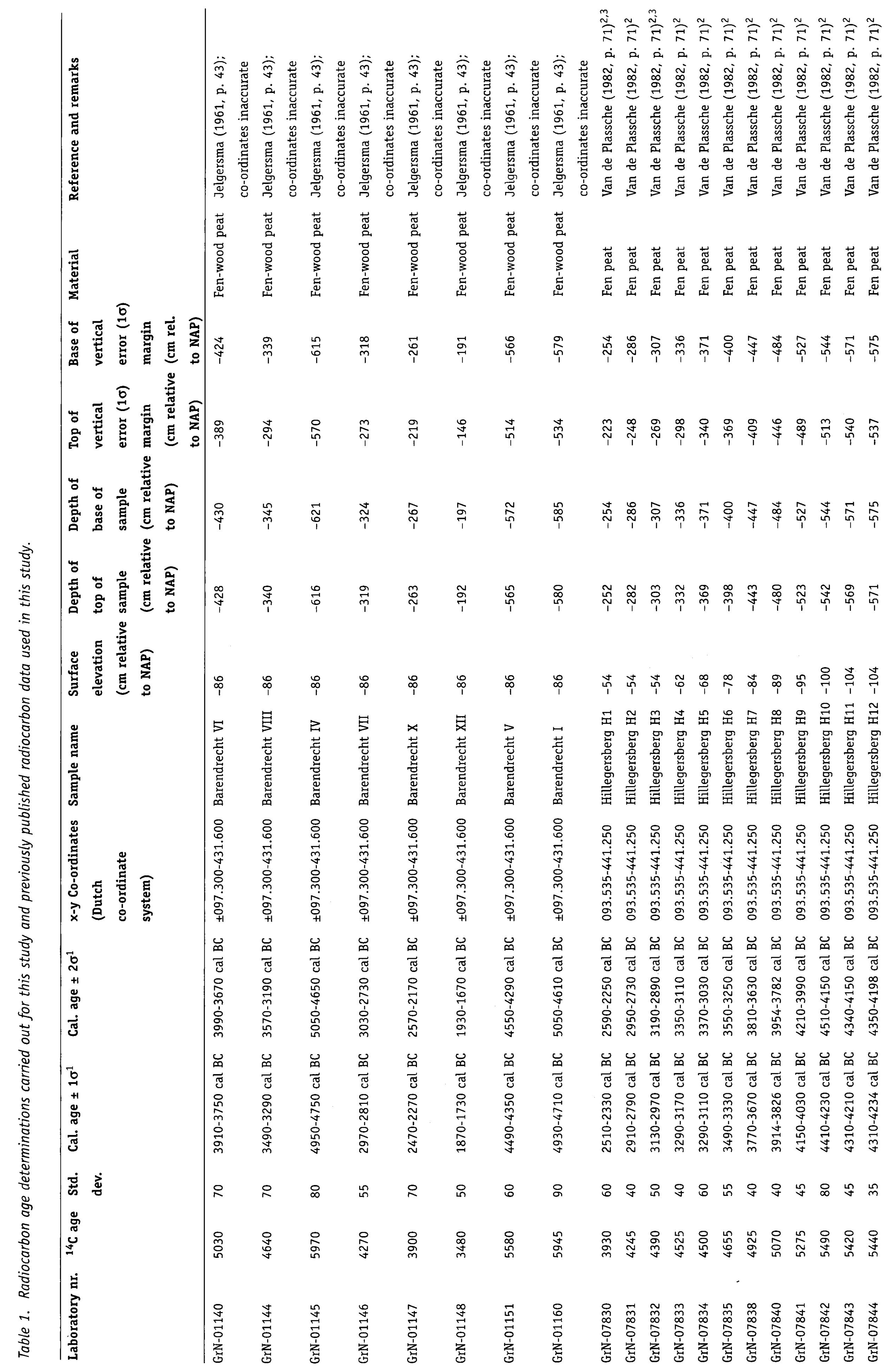




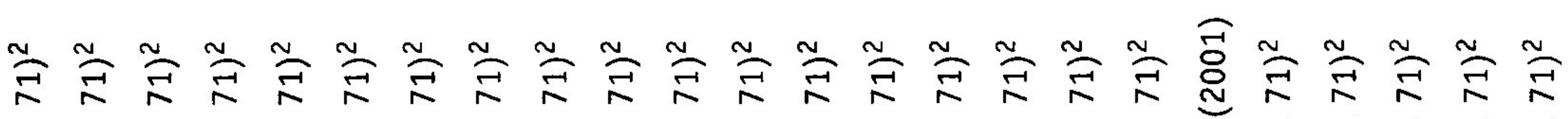

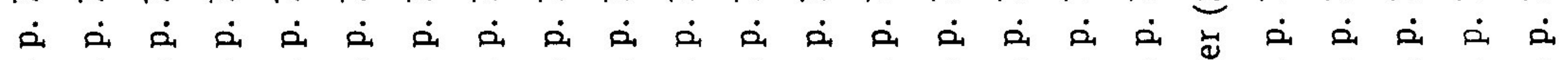

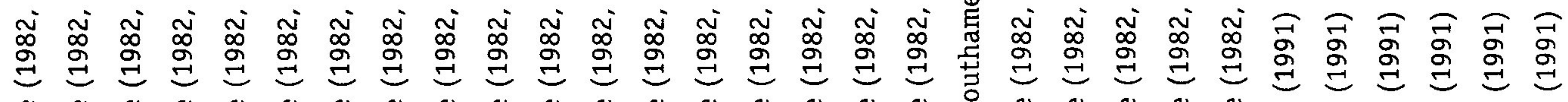

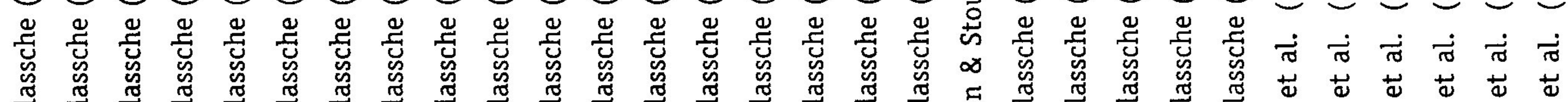

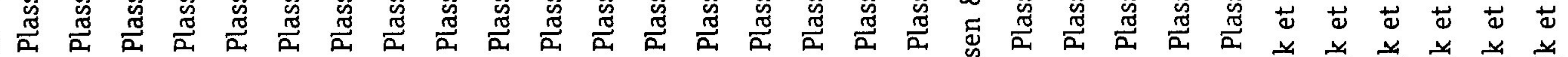

\&

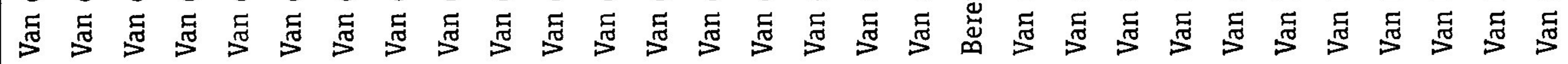

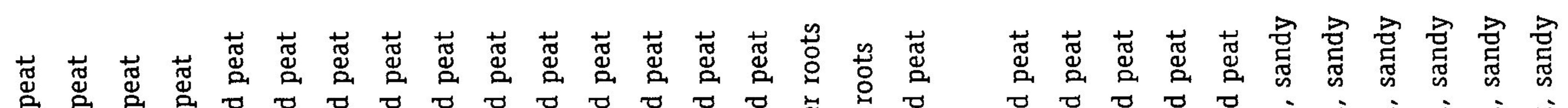

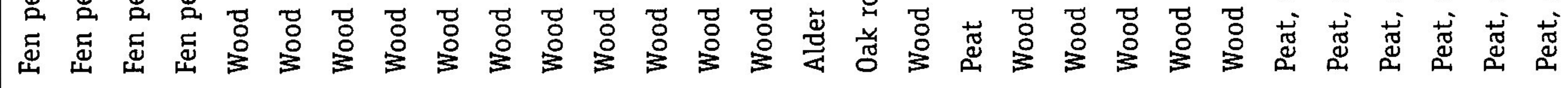

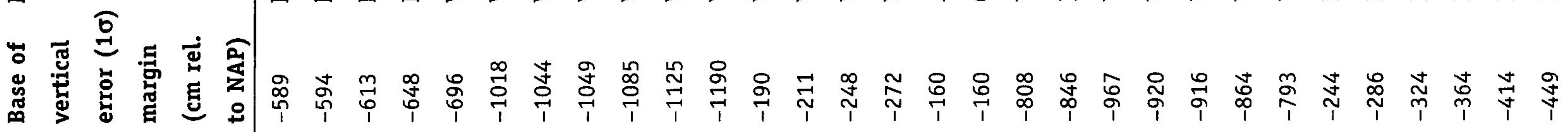

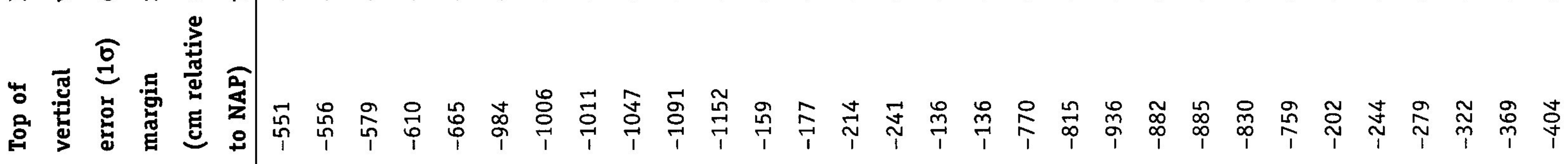

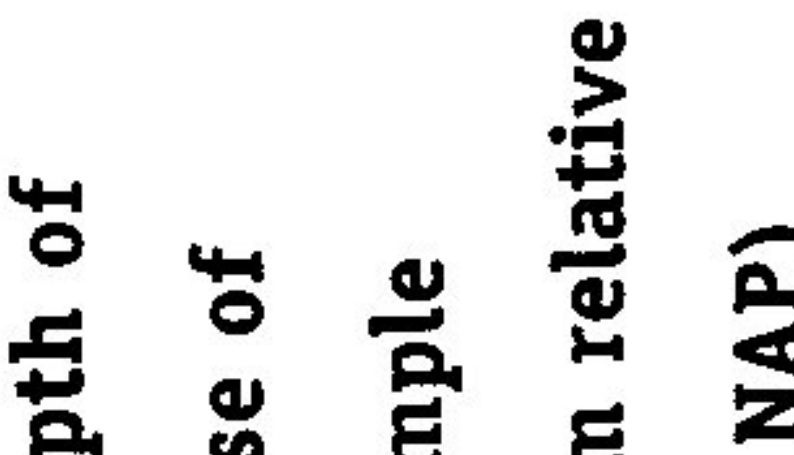

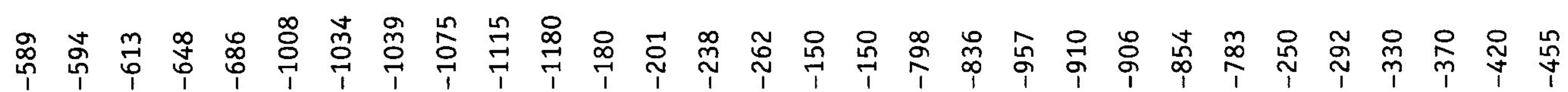

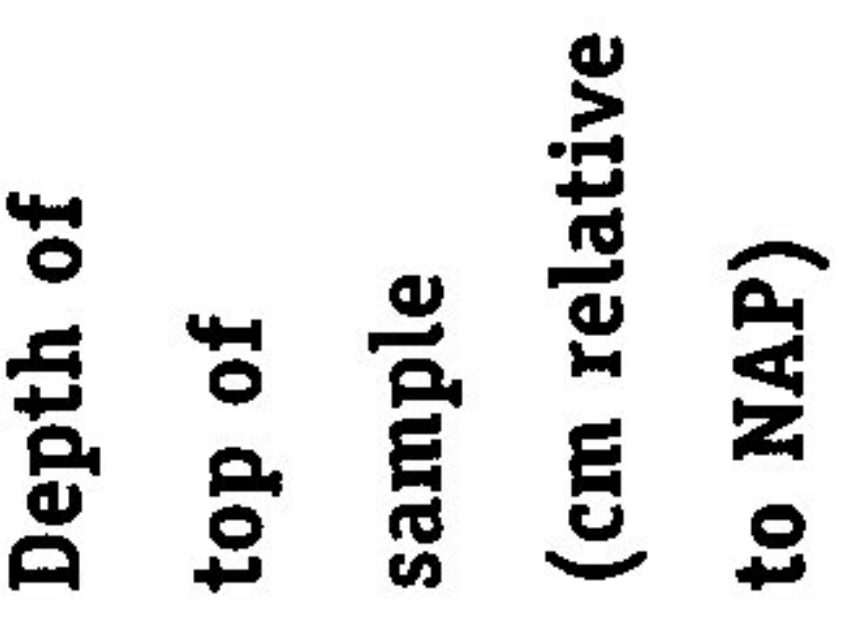

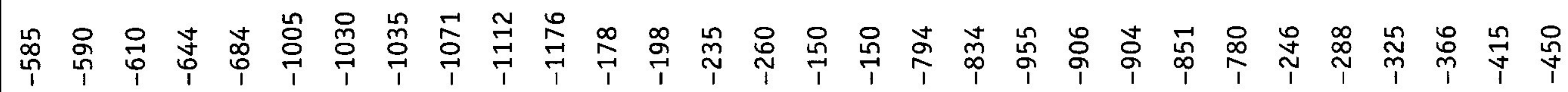

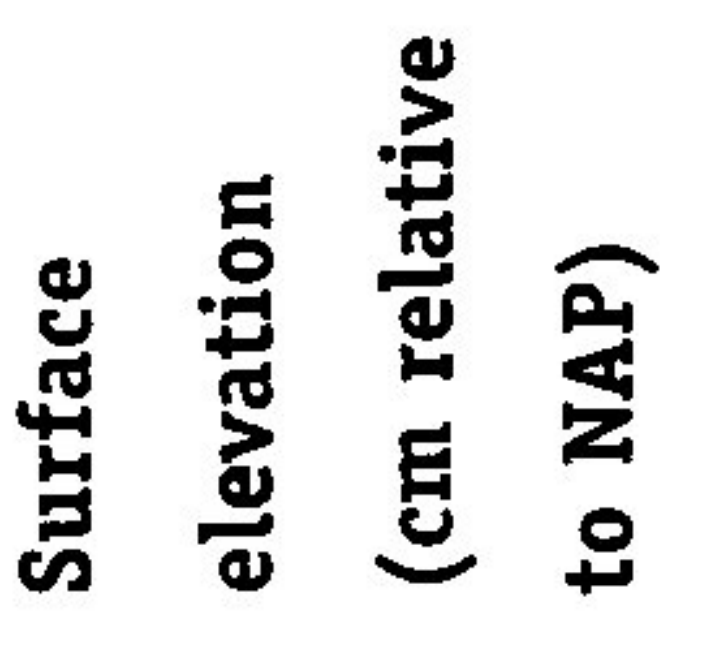

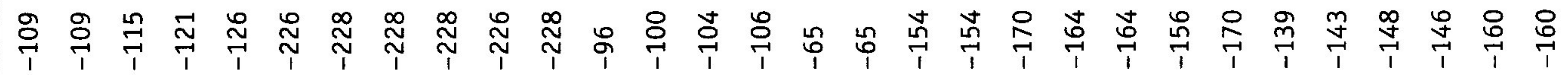

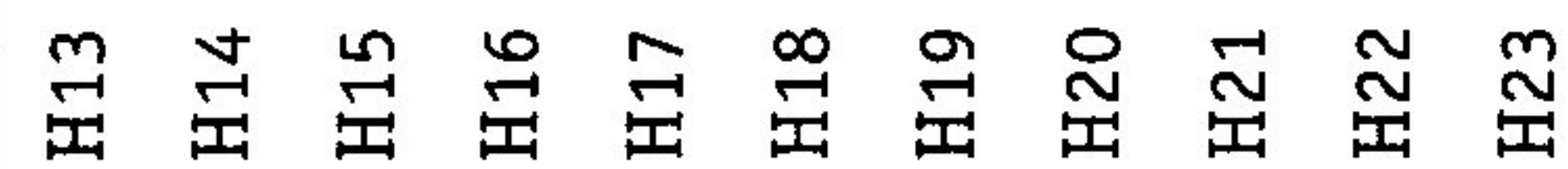

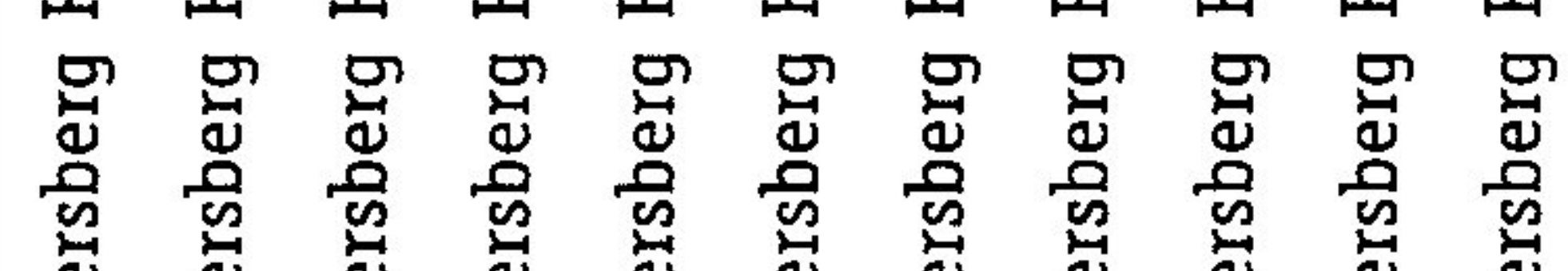

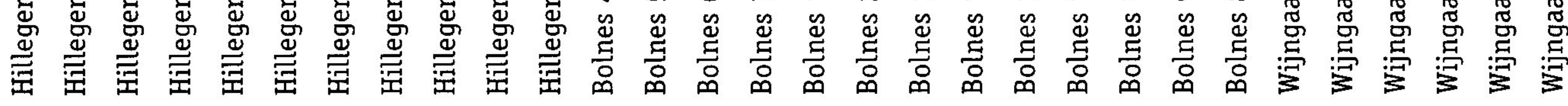

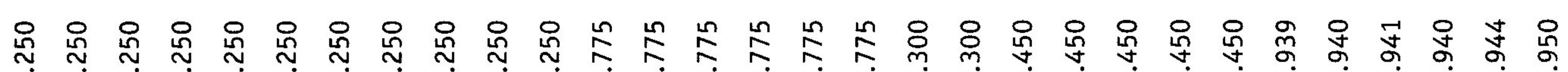
出

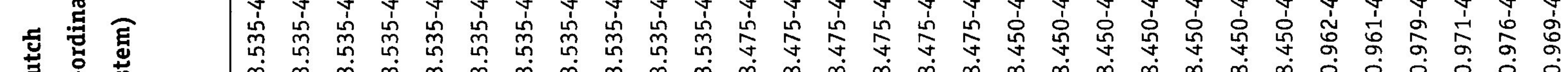

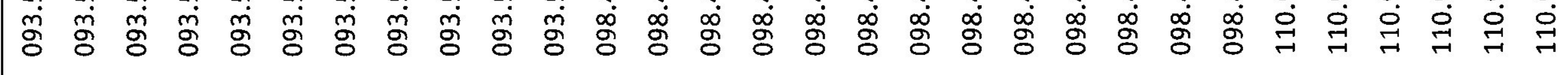

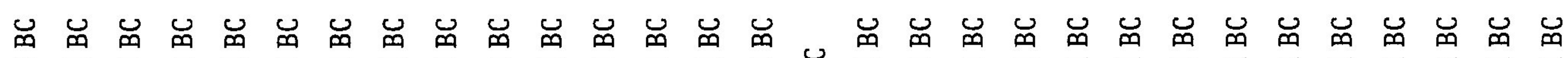

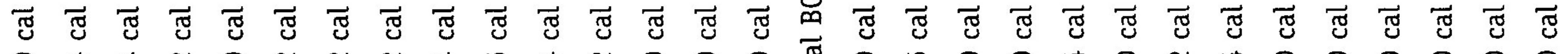

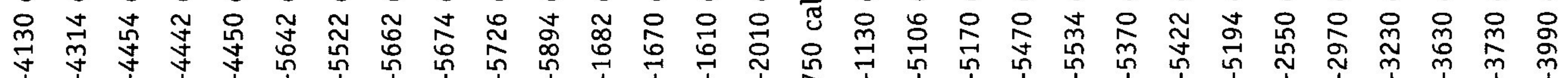

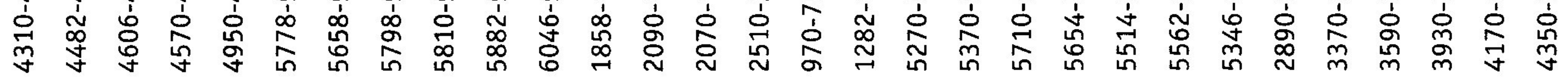

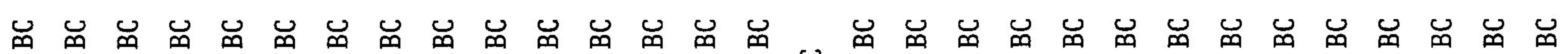
तु तु

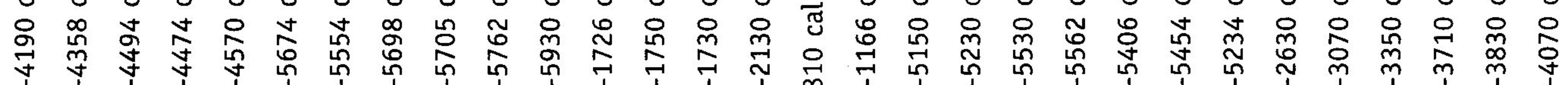

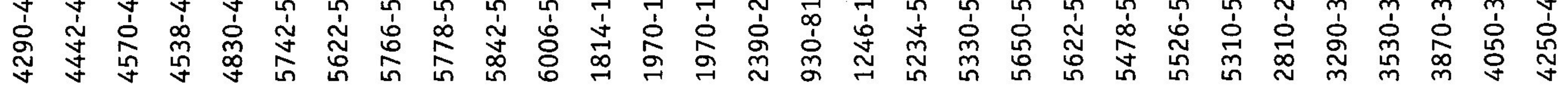

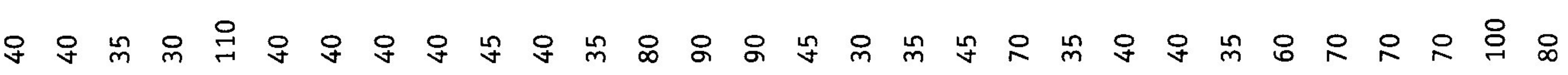

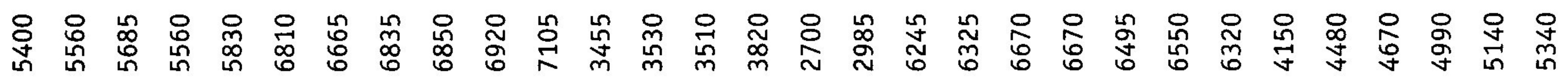




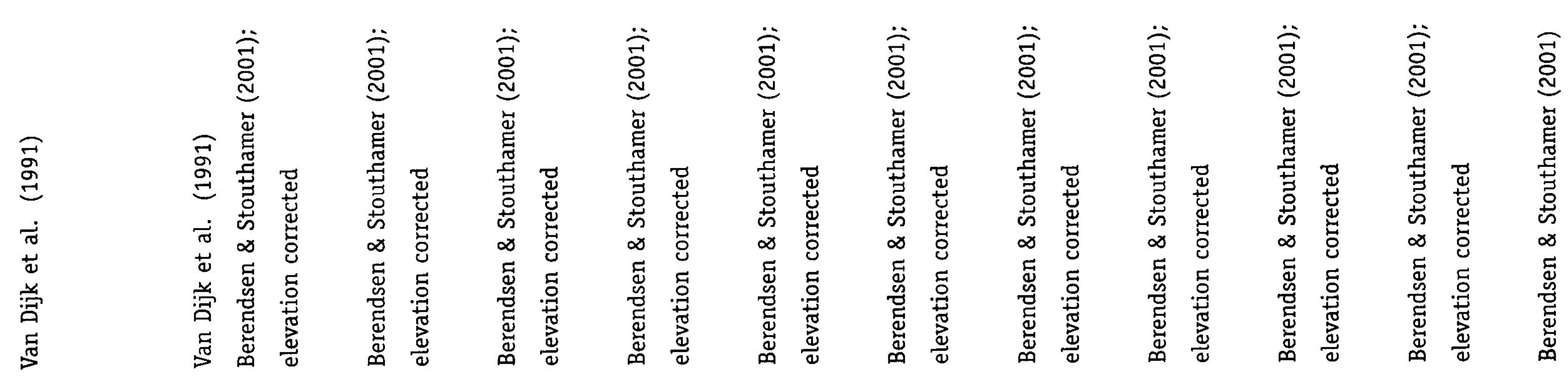

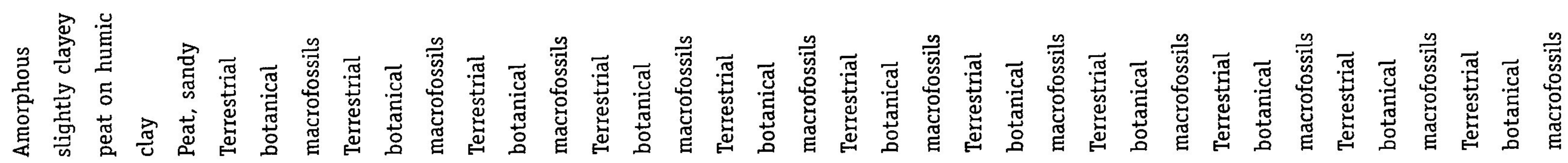

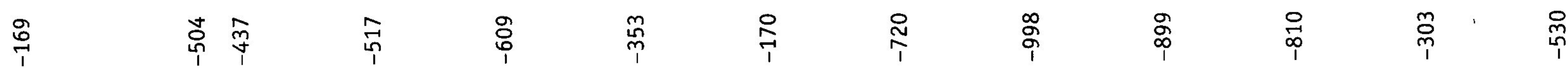

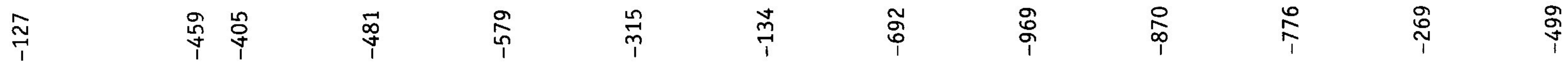

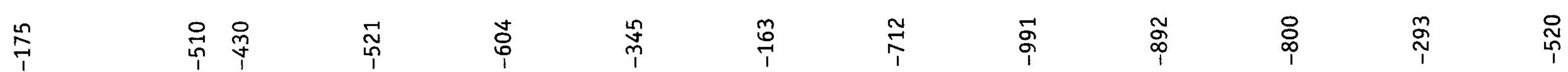

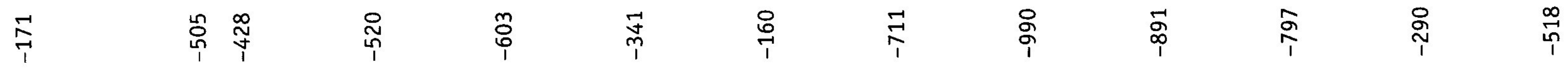

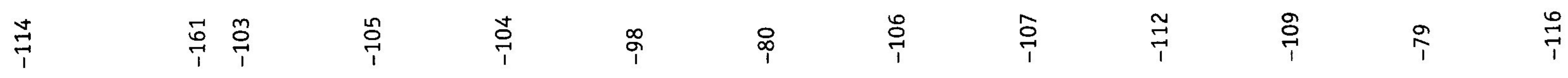

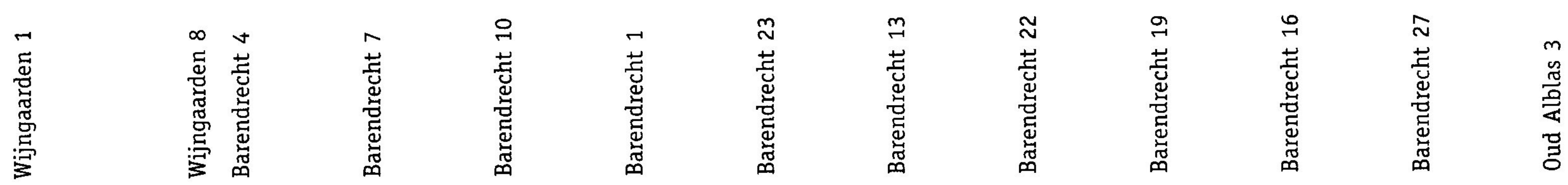

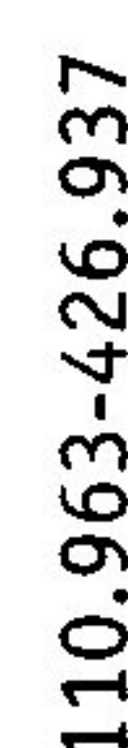

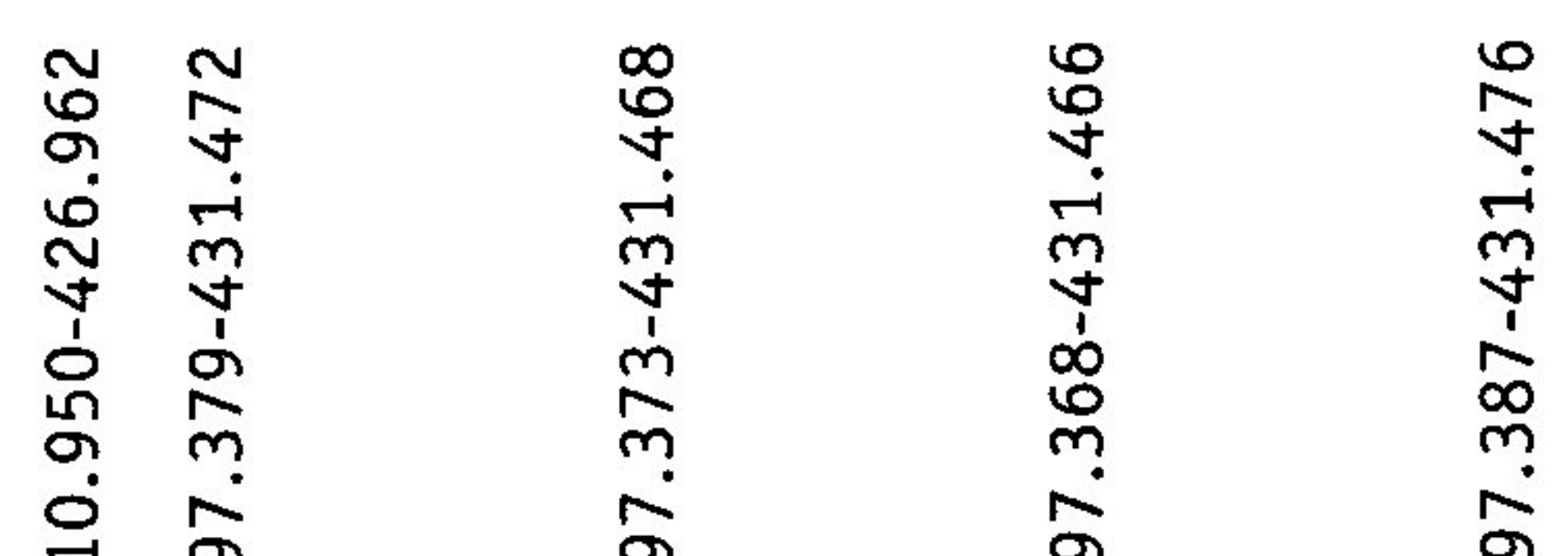

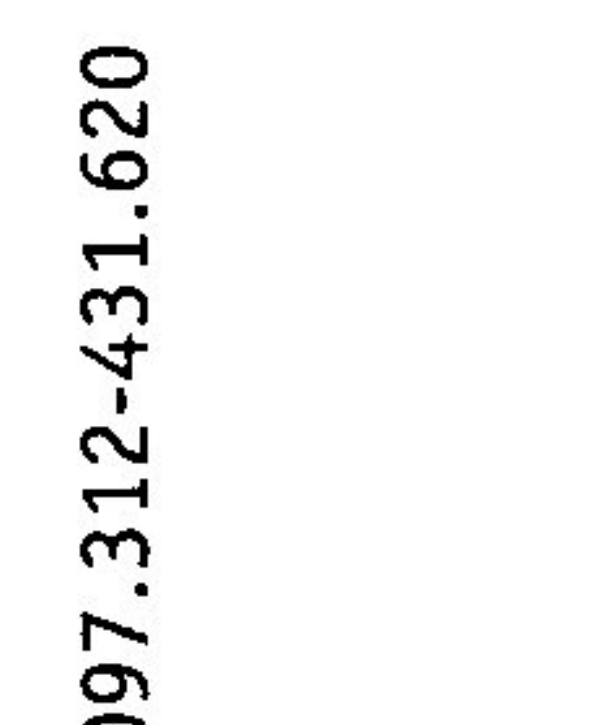

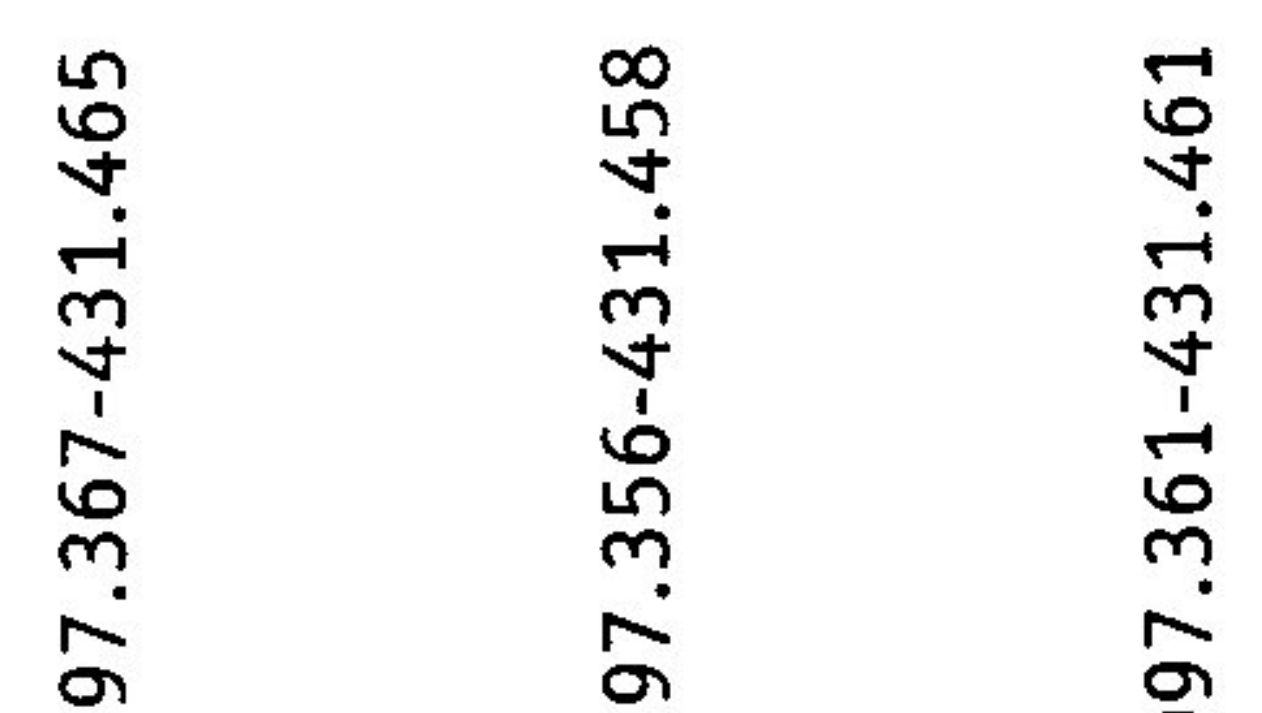

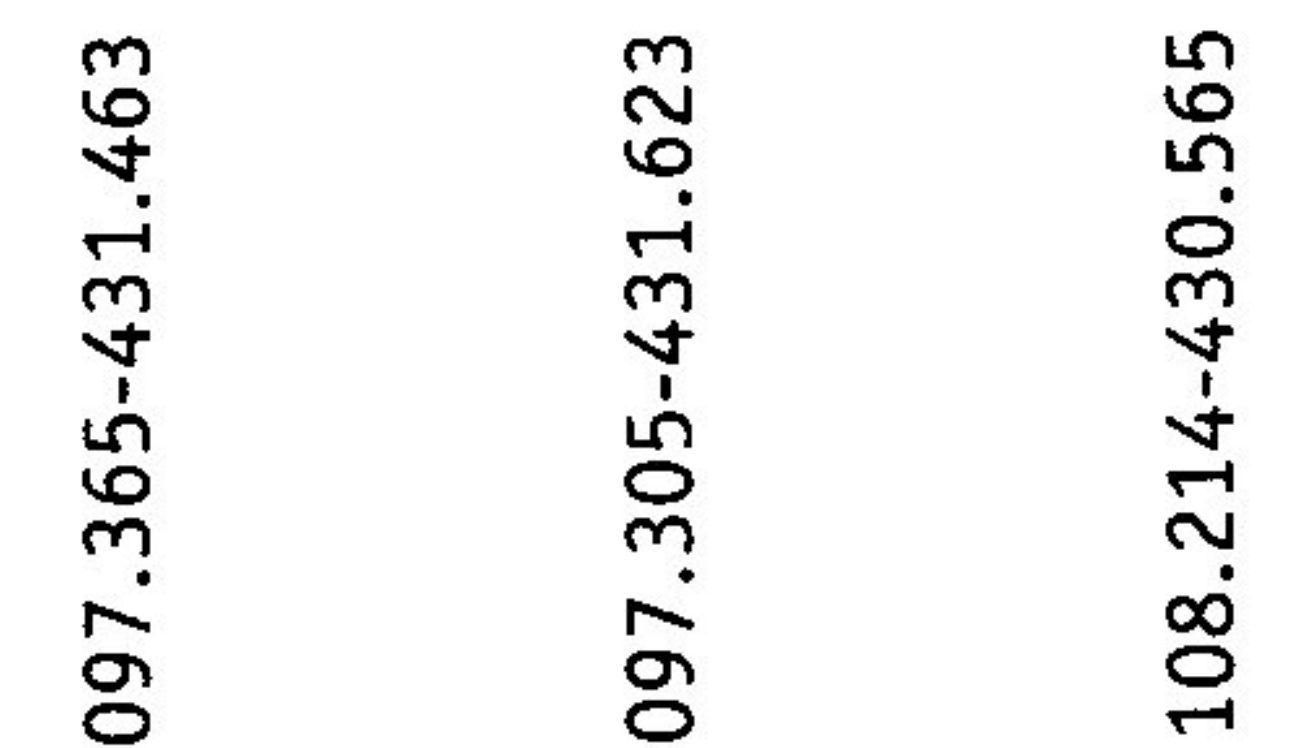

迎

శึ

品免

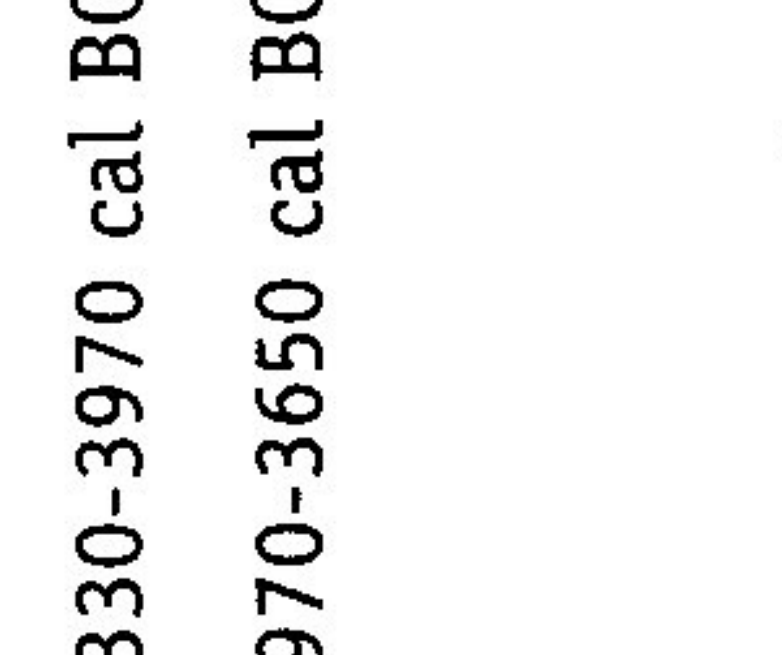

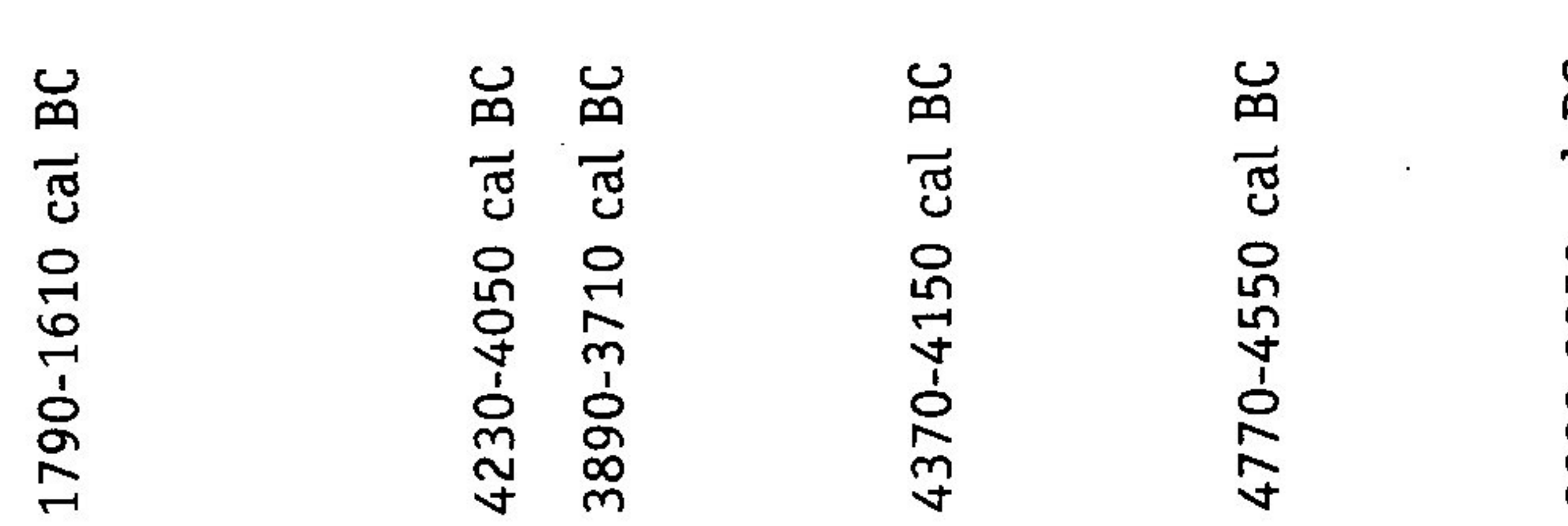

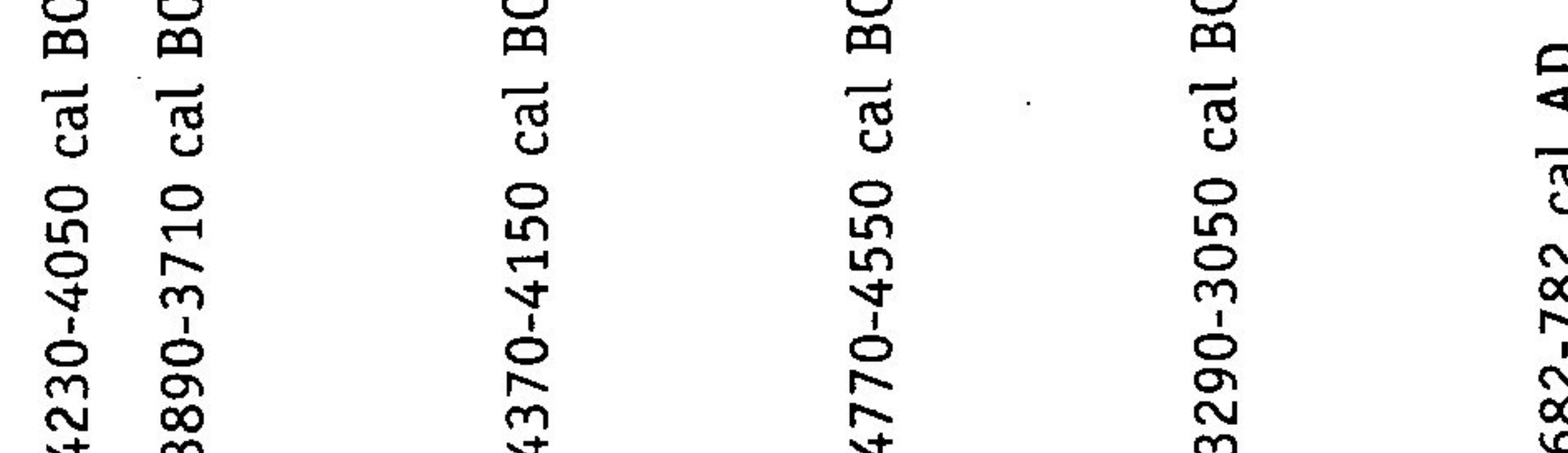

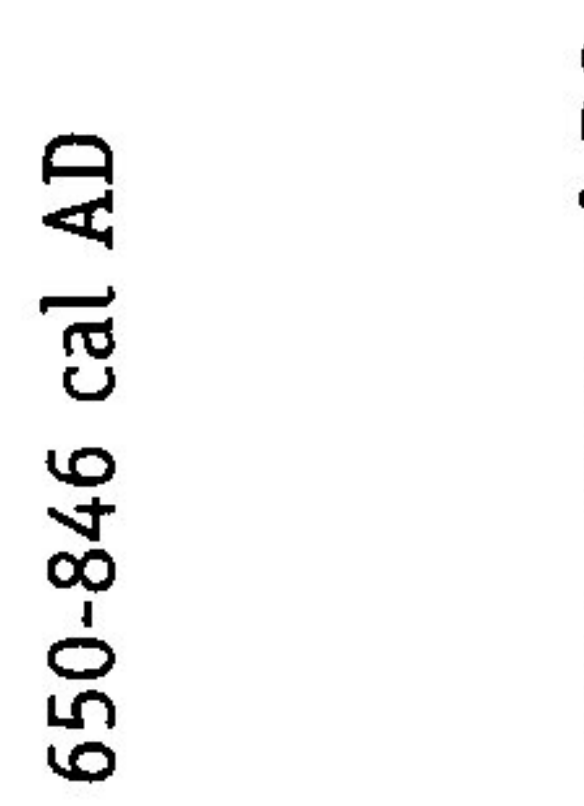

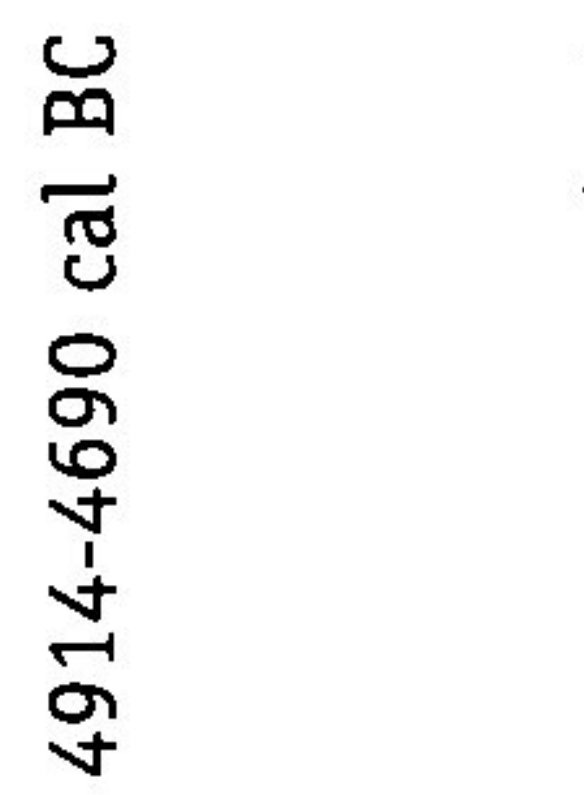

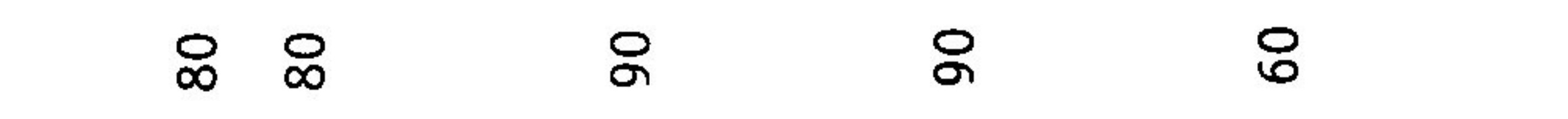

व्ष

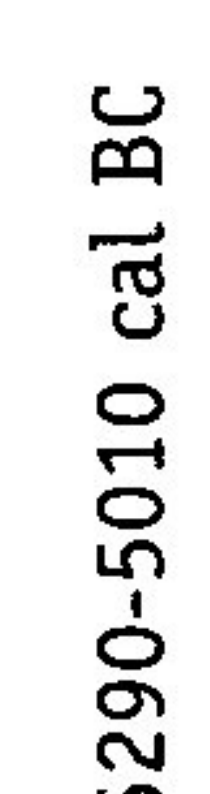

崫崖

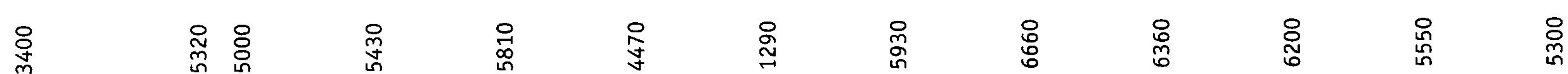

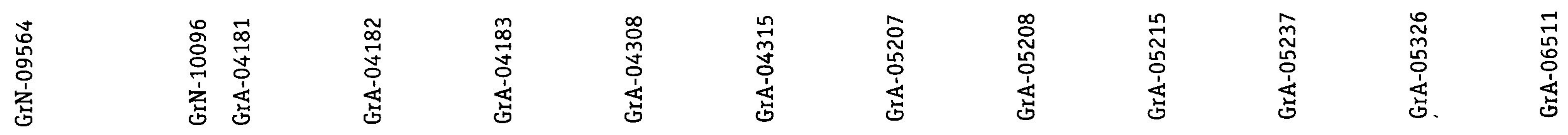




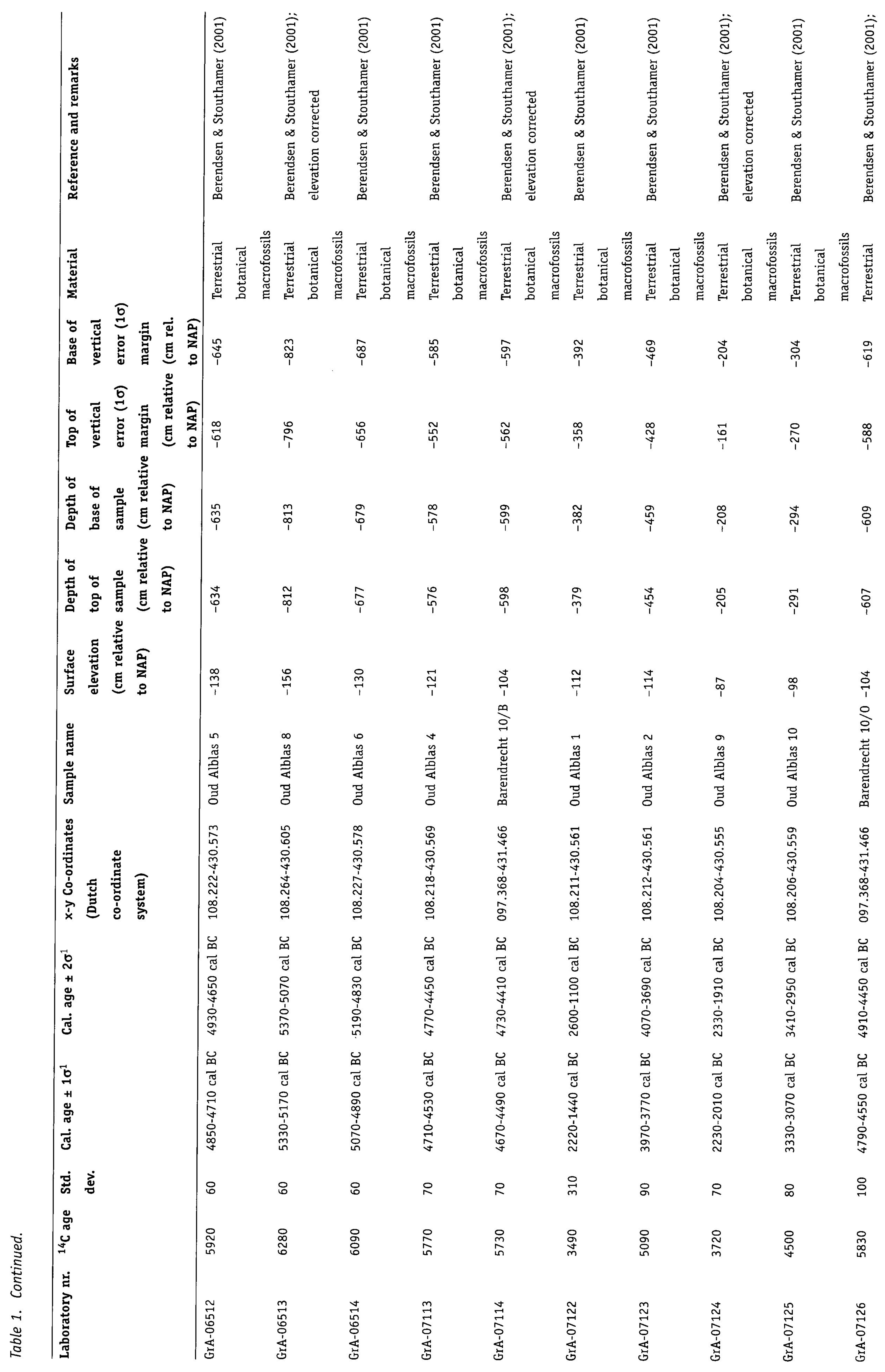




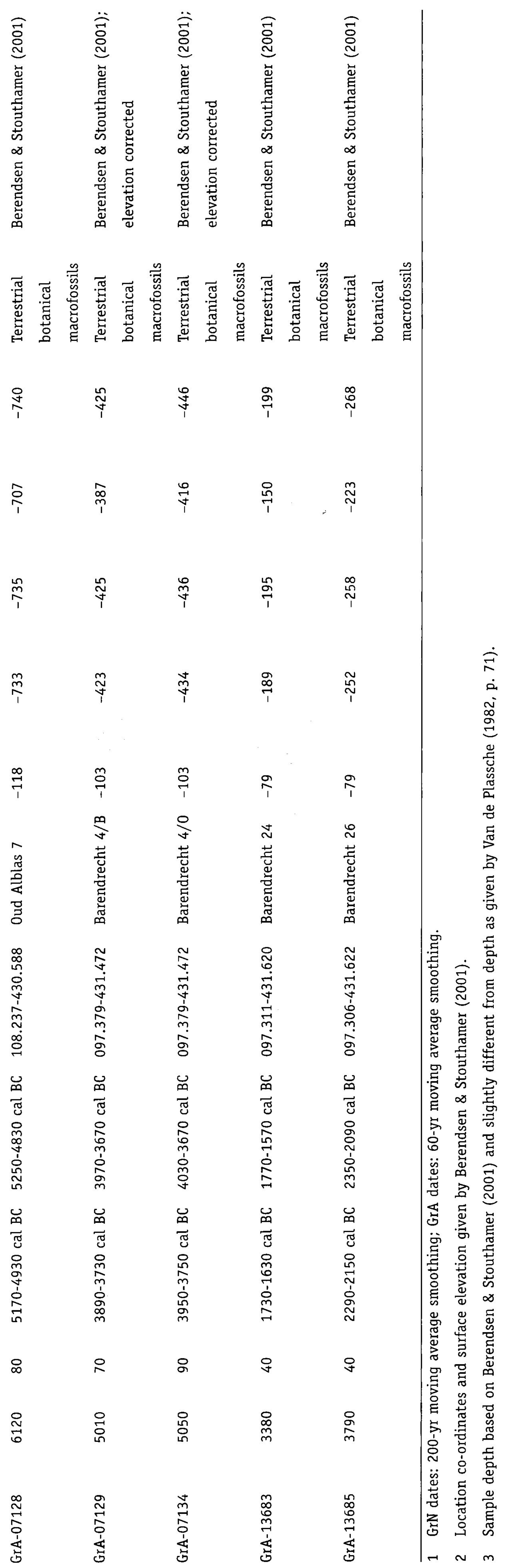

a) Wood peat: Törnqvist et al. (1998) and Van de Plassche et al. (2005) proposed, rather optimistically, that wood peat is formed within a vertical range of $\pm 10 \mathrm{~cm}$ relative to the local average groundwater level. Here, we use a vertical uncertainty of $\pm 20 \mathrm{~cm}$. All new AMS-dated samples consisted of wood peat.

b) Reed peat or reed-sedge peat: this kind of peat forms below the average water level. However, the environment in which the samples were formed (transgressive peats on the flanks of aeolian dunes) excludes significant water depths. Hence we accept an average water depth of $10 \mathrm{~cm}$ for reed peat and reed-sedge peat samples and add the same uncertainty margin of $\pm 20 \mathrm{~cm}$ as for samples of wood peat.

4. Uncertainties related to compaction. Compaction (Van de Plassche, 1980) depends mainly on depth, overburden and kind of peat. Even if all samples were collected at or only slightly above the compaction-free surface of dune sand, some compaction needs to be taken into account. We applied the same correction factors as Van de Plassche et al. (2005), i.e., a minimum correction factor of 1.5 (for the base of the dated sample) and a maximum correction factor of 2.5 (for the top of the dated sample). For instance, a $5 \mathrm{~cm}$ thick sample, taken at $10 \mathrm{~cm}$ above the dune surface, is 'decompacted' to $15-37.5 \mathrm{~cm}$ above the dune surface.

5. Because the correction factors mentioned under point 4 are averages from a wider range of possible correction factors, we added an uncertainty margin for compaction of $\pm 10 \mathrm{~cm}$.

Instead of summing vertical errors and uncertainties to obtain a maximum vertical range, as has been done in previous palaeowater-level studies (e.g., Törnqvist et al., 1998; Makaske et al., 2003; Van de Plassche et al., 2005), we calculated a total vertical standard deviation based on the various vertical errors and uncertainties mentioned above (except the 'oneway upward corrections' $3 \mathrm{~b}$ and 4 ) that are considered as estimates of the $2 \sigma$ error range (Table 1 ; a table containing the details of the calculations can be downloaded from: $h t t p: / / w w w . g e o . u u . n l / f g /$ palaeogeography). Although this total vertical standard deviation necessarily is based on estimates, this statistical approach is more consistent with the way age-error margins (see below) are represented. In plotting the samples in time-depth graphs, we took the top of the dune sand as the lower limit of the vertical error range, because errors relating to its depth are negligible.

\section{Age-error margins}

Age-error margins are determined by the standard deviation in the dated radiocarbon samples, as given by the laboratory. All radiocarbon ages were calibrated using CAL25 (Stuiver \& Van der Plicht, 1998). AMS-dated samples were calibrated using a 60 -year moving average curve. Conventionally dated bulk peat 


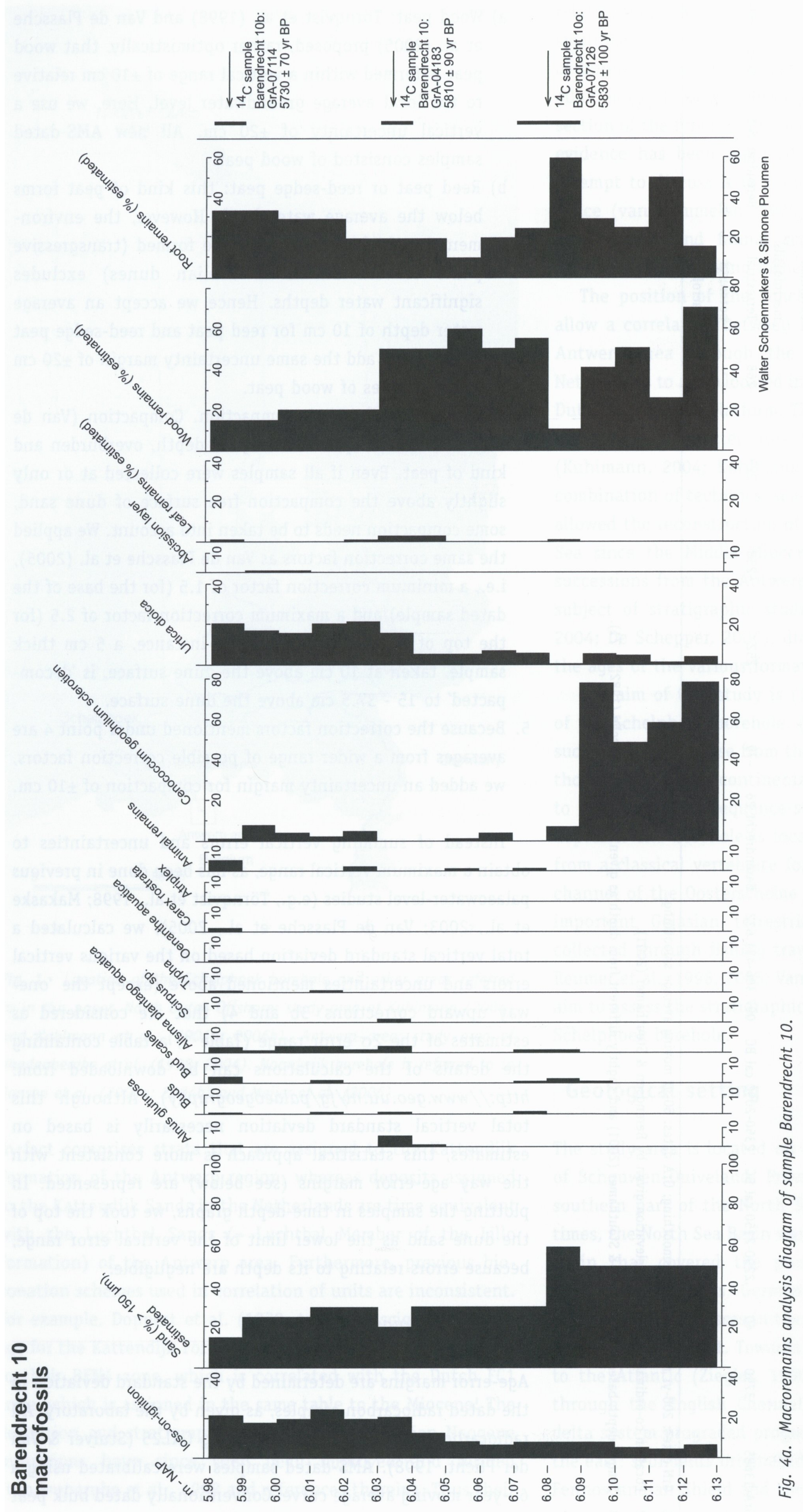

Netherlands Journal of Geosciences - Geologie en Mijnbouw | $86-4 \mid 2007$ 


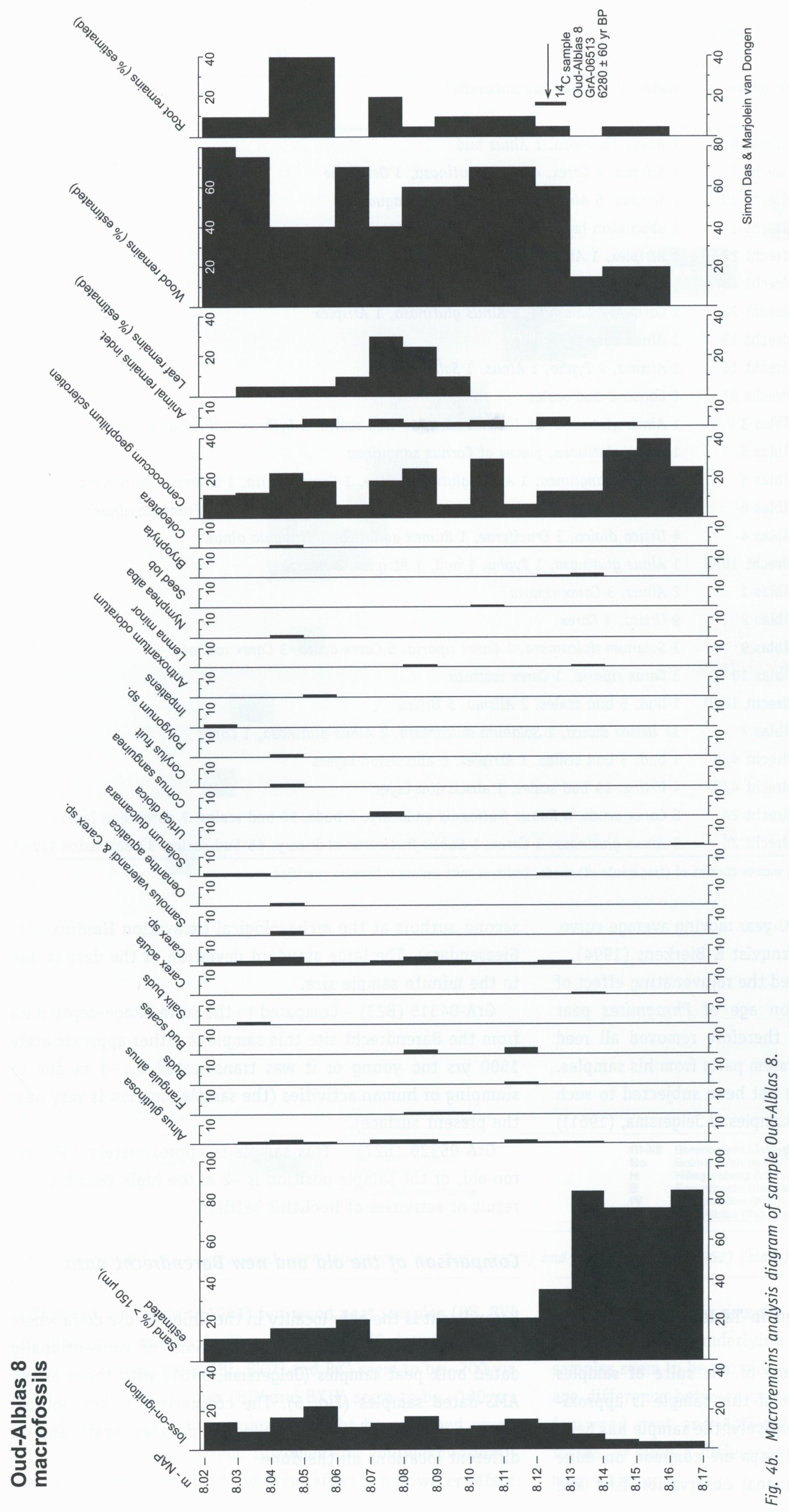


Table 2. Macroremains used for radiocarbon age determination.

\begin{tabular}{|c|c|c|c|}
\hline $\begin{array}{l}\text { Laboratory } \\
\text { number }\end{array}$ & $\begin{array}{l}{ }^{14} \mathrm{C} \text { age } \\
\text { (yr BP) }\end{array}$ & Sample name & Material / dated macrofossils ${ }^{1}$ \\
\hline GrA-04181 & $5000 \pm 80$ & Barendrecht 4 & 2 Alnus glutinosa, 1 Alnus bud \\
\hline GrA-04182 & $5430 \pm 90$ & Barendrecht 7 & 2 Scirpus, 2 Carex, 4 Alnus glutinosa, 3 Oenanthe \\
\hline GrA-04183 & $5810 \pm 90$ & Barendrecht 10 & 2 Scirpus, 5 Alnus, 3 Alisma plantago aquatica \\
\hline GrA-04308 & $4470 \pm 60$ & Barendrecht 1 & 2 abscission layers, 2 Urtica, 1 Coleoptera fragment \\
\hline GrA-04315 & $1290 \pm 50$ & Barendrecht 23 & 1 Atriplex, 1 Alisma, 1 Alnus glutinosa, 3 Polygonum \\
\hline GrA-05207 & $5930 \pm 50$ & Barendrecht 13 & 1 Cornus sanguinea \\
\hline GrA-05208 & $6660 \pm 60$ & Barendrecht 22 & 2 Cornus, 2 Solanum, 2 Alnus glutinosa, 1 Atriplex \\
\hline GrA-05215 & $6360 \pm 50$ & Barendrecht 19 & 1 Alnus cone \\
\hline GrA-05237 & $6200 \pm 50$ & Barendrecht 16 & 3 Alisma, 2 Typha, 1 Alnus, 1 Solanum \\
\hline GrA-05326 & $5550 \pm 60$ & Barendrecht 27 & 2 Carex, 2 bud scales \\
\hline GrA-06511 & $5300 \pm 60$ & Oud Alblas 3 & 1 Alnus glutinosa, 26 Urtica dioica, 17 bud scales, 3 Lythrum salicaria, 1 bud \\
\hline GrA-06512 & $5920 \pm 60$ & Oud Alblas 5 & 1 Alnus glutinosa, pieces of Cornus sanguinea \\
\hline GrA-06513 & $6280 \pm 60$ & Oud Alblas 8 & 1 Cornus sanguinea, 1 Alnus glutinosa cone, 1 Carex riparia, 1 Solanum dulcamara \\
\hline GrA-06514 & $6090 \pm 60$ & Oud Alblas 6 & 1 Alisma plantago aquatica, 1 abscission layer, 12 Carex acuta, 4 Frangula alnus \\
\hline GrA-07113 & $5770 \pm 70$ & Oud Alblas 4 & 4 Urtica dioica, 3 Cruciferae, 1 Rumex aquatica, 1 Frangula alnus \\
\hline GrA-07114 & $5730 \pm 70$ & Barendrecht 10/B & 1 Alnus glutinosa, 1 Typha, 1 bud, 1 Atriplex, 3 Alisma \\
\hline GrA-07122 & $3490 \pm 310$ & Oud Alblas 1 & 2 Alnus, 3 Carex riparia \\
\hline GrA-07123 & $5090 \pm 90$ & Oud Alblas 2 & 9 Urtica, 1 Carex \\
\hline GrA-07124 & $3720 \pm 70$ & Oud Alblas 9 & 3 Solanum dulcamara, 1 Carex riparia, 5 Carex acuta, 3 Carex rostrata \\
\hline GrA-07125 & $4500 \pm 80$ & Oud Alblas 10 & 3 Carex riparia, 1 Carex rostrata \\
\hline GrA-07126 & $5830 \pm 100$ & Barendrecht $10 / 0$ & 1 bud, 5 bud scales, 2 Alisma, 5 Urtica \\
\hline GrA-07128 & $6120 \pm 80$ & Oud Alblas 7 & 37 Urtica dioica, 1 Solanum dulcamara, 2 Alnus glutinosa, 1 Carex \\
\hline GrA-07129 & $5010 \pm 70$ & Barendrecht 4/B & 1 bud, 3 bud scales, 1 Atriplex, 6 abscission layers \\
\hline GrA-07134 & $5050 \pm 90$ & Barendrecht $4 / 0$ & 4 Urtica, 14 bud scales, 1 abscission layer \\
\hline GrA-13683 & $3380 \pm 40$ & Barendrecht 24 & 8 Carex acuta, 4 Rubus fruticosus endocarp, 2 buds, 96 bud scales, 7 abscission layers \\
\hline GrA-13685 & $3790 \pm 40$ & Barendrecht 26 & 3 Alnus glutinosa, 3 Carex, 1 Rubus fruticosus endocarp, 65 bud scales, 33 abscission layers \\
\hline
\end{tabular}

1 Dated macrofossils indicated by species names consist of (fragments of) seeds, fruits or nuts unless otherwise specified.

samples were calibrated using a 200-year moving average curve, following recommendations by Törnqvist \& Bierkens (1994).

Streif $(1971,1972)$ demonstrated the rejuvenating effect of reed rhizomes on the radiocarbon age of Phragmites peat samples. Van de Plassche (1982) therefore removed all reed rhizomes, rootlets and subsurface stem parts from his samples. Theoretically, samples which have not been subjected to such preparation (e.g., the Barendrecht samples of Jelgersma, (1961)) may have ages that are too young.

\section{Results}

\section{Rejected data}

The dating results are summarised in Table 1 . The following index points were rejected:

GrA-07122 (A1) - Given the age of the suite of samples from the Oud-Alblas site, the age of this sample is approximately 1300 yrs too young. Alternatively, the sample has been translocated $\sim 2 \mathrm{~m}$ by a slump. Slumps are common on dune slopes that drowned quickly (personal observation first and second authors at the archaeological excavation HardinxveldGiessendam). The large standard deviation of the date is due to the minute sample size.

GrA-04315 (B23) - Compared to the suite of age-depth data from the Barendrecht site this sample is either approximately 1500 yrs too young or it was translocated by $\sim 1 \mathrm{~m}$ due to slumping or human activities (the sample location is very near the present surface).

GrA-05326 (B27) - This sample is approximately 1500 yrs too old, or the sample position is $\sim 2 \mathrm{~m}$ too high, possibly as a result of activities of Neolithic settlers.

\section{Comparison of the old and new Barendrecht data}

Barendrecht is the only locality in the Rhine-Meuse delta where we can compare the age-depth positions of conventionally dated bulk peat samples (Jelgersma, 1961) with those of our AMS-dated samples (Fig. 5). The comparison is not optimal because the samples were collected decades apart and at different locations on the dune. 


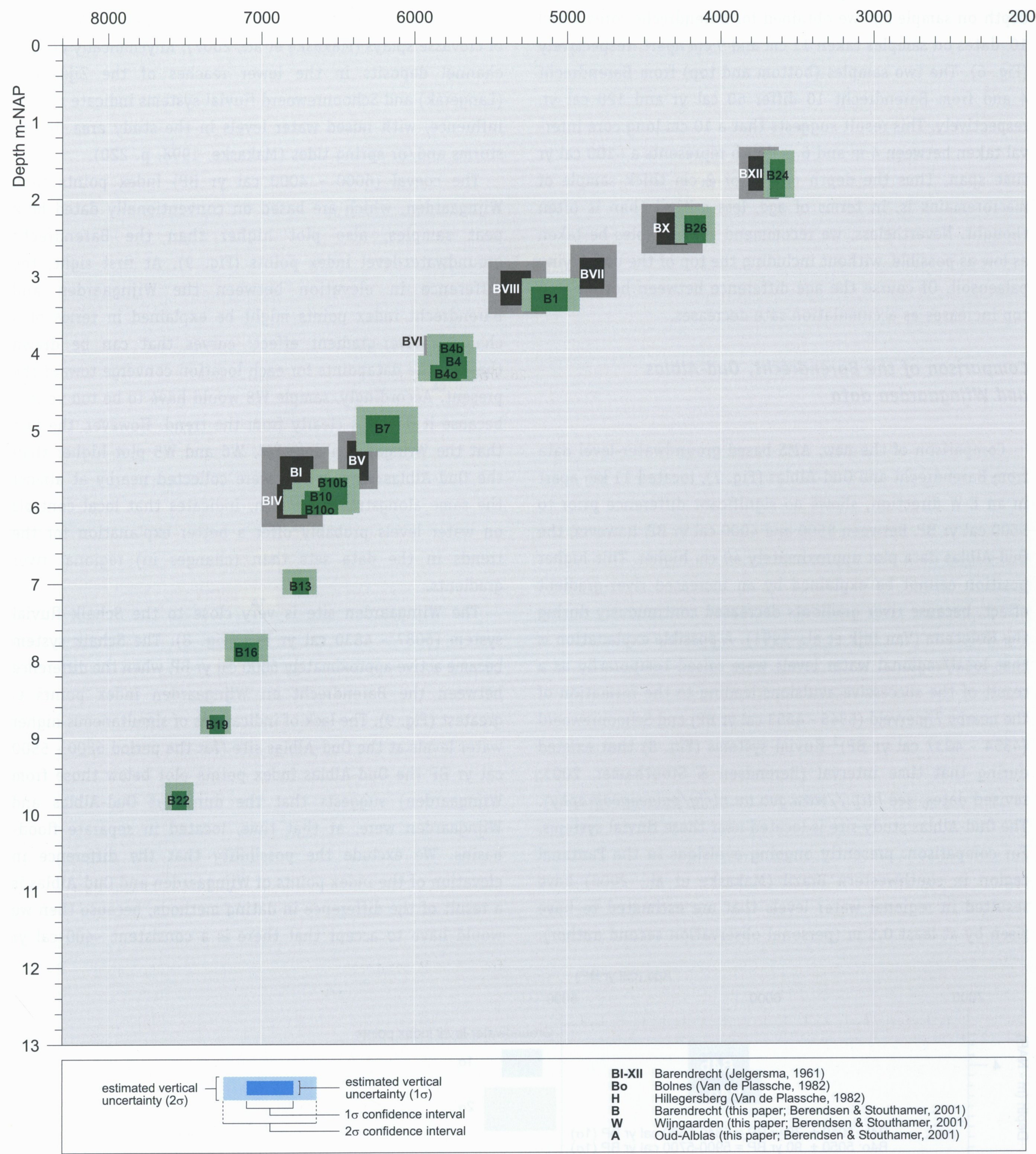

Fig. 5. Barendrecht groundwater-level index points from this study (green) and from Jelgersma (1961) (black).

Three of Jelgersma's (1961) fen-wood peat samples (BV, BVI and BVII) plot exactly in line with the AMS-dated samples. Three of her index points (BI, BVIII and BX) seem to be $\sim 200$ yrs too old, while two samples (BIV and BXII) seem to be $\sim 100 \mathrm{yrs}$ too old (rather than too young, as might be expected given the possible presence of reed rhizomes and younger rootlets). Sample ages that seem too old may reflect a hardwater effect or inclusion in the sample of 'old' organic carbon from the humic top of the underlying soil. Although five of Jelgersma's samples seem to be too old, we see no evidence for a systematic age difference between conventionally dated bulk samples of fen-wood peat and AMS-dated samples of terrestrial macrofossils. If such a difference exists, it is, on average, smaller than $\sim 150$ yr. 
In order to investigate the influence of in-core sample depth on sample age we obtained for Barendrecht cores 4 and 10 , dates on samples taken $11 \mathrm{~cm}$ and $9 \mathrm{~cm}$ apart, respectively (Fig. 6). The two samples (bottom and top) from Barendrecht 4 and from Barendrecht 10 differ $60 \mathrm{cal}$ yr and $120 \mathrm{cal} \mathrm{yr}$, respectively. This result suggests that a $10 \mathrm{~cm}$ long core interval taken between $4 \mathrm{~m}$ and $6 \mathrm{~m}$ depth represents a $\sim 100 \mathrm{cal}$ yr time span. Thus the depth of a 1 or $2 \mathrm{~cm}$ thick sample of macroremains is, in terms of age, less critical than is often thought. Nevertheless, we recommend that samples be taken as low as possible, without including the top of the underlying palaeosoil. of course the age difference between bottom and top increases as accumulation rate decreases.

\section{Comparison of the Barendrecht, Oud-Alblas and Wijngaarden data}

Comparison of the new, AMS-based groundwater-level data from Barendrecht and Oud-Alblas (Fig. 7), located $11 \mathrm{~km}$ apart in an $\mathrm{E}-\mathrm{W}$ direction, shows no significant difference prior to $5500 \mathrm{cal}$ yr BP. Between 5500 and $4000 \mathrm{cal}$ yr BP, however, the Oud-Alblas data plot approximately $40 \mathrm{~cm}$ higher. This higher position cannot be explained by an increased river-gradient effect, because river gradients decreased continuously during the Holocene (Van Dijk et al., 1991). A possible explanation is that local/regional water levels were raised temporarily as a result of the successive avulsions leading to the formation of the nearby Zijderveld (5345 - 4653 cal yr BP) and Schoonrewoerd $\left(4354\right.$ - 4037 cal yr BP) ${ }^{1}$ fluvial systems (Fig. 8) that existed during that time interval (Berendsen \& Stouthamer, 2001; revised dates, see $h t t p: / / w w w . g e o . u u . n l / f g /$ palaeogeography). The Oud-Alblas study site is located near these fluvial systems. For comparison: presently ongoing avulsions in the Pantanal region in southwestern Brazil (Makaske et al., 2006) have resulted in regional water levels that are estimated to have risen by at least $0.5 \mathrm{~m}$ (personal observation second author).
The Schoonrewoerd avulsion in particular is interpreted to have been a similar catastrophic event with extensive formation of crevasse splays (Makaske et al., 2007). Rhythmically bedded channel deposits in the lower reaches of the Zijderveld (Langerak) and Schoonrewoerd fluvial systems indicate marine influence, with raised water levels in the study area due to storms and/or spring tides (Makaske, 1998, p. 220).

The coeval (6000 - 4000 cal yr BP) index points from Wijngaarden, which are based on conventionally dated bulk peat samples, also plot higher than the Barendrecht groundwater-level index points (Fig. 9). At first sight, the difference in elevation between the Wijngaarden and Barendrecht index points might be explained in terms of a changing river-gradient effect: curves that can be drawn through the datapoints for each location converge toward the present. Accordingly, sample W8 would have to be too young, because it deviates clearly from the trend. However, the fact that the Wijngaarden data W7, W6 and W5 plot higher than the Oud-Alblas data, which were collected nearby at almost the same alongstream position, indicates that local controls on water levels probably offer a better explanation for the trends in the data sets than (changes in) regional river gradients.

The Wijngaarden site is very close to the Schaik fluvial system (6087 - 4830 cal yr BP) (Fig. 8). The Schaik system became active approximately $6000 \mathrm{cal}$ yr $\mathrm{BP}$, when the difference between the Barendrecht en Wijngaarden index points is greatest (Fig. 9). The lack of indications of simultaneous higher water levels at the Oud-Alblas site (for the period 6200 - 5500 cal yr BP the Oud-Alblas index points plot below those from Wijngaarden) suggests that the dunes at Oud-Alblas and Wijngaarden were, at that time, located in separate floodbasins. We exclude the possibility that the difference in elevation of the index points of Wijngaarden and Oud-Alblas is a result of the difference in dating methods, because then we would have to accept that there is a consistent $\sim 400 \mathrm{cal} \mathrm{yr}$

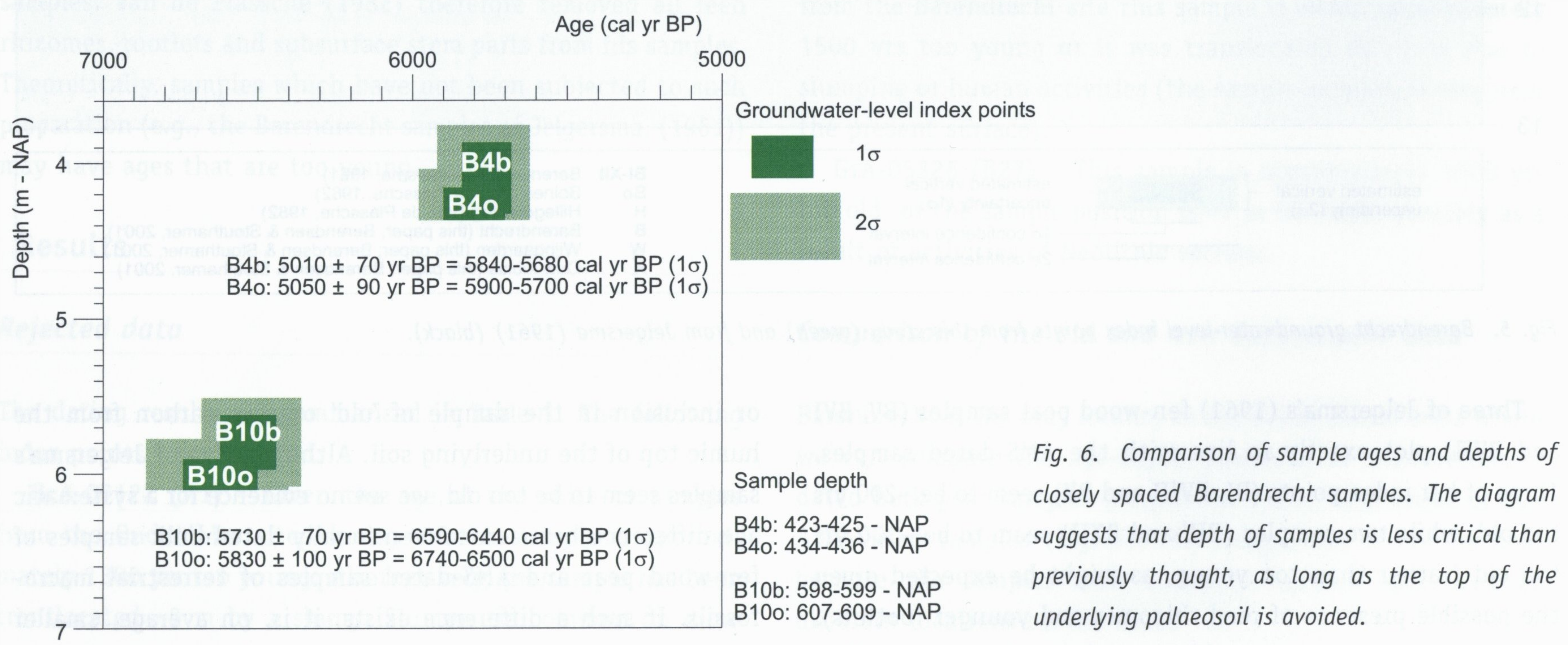

1 Makaske et al. (2007) proposed a shorter period of activity for the Schoonrewoerd system: 3900-3800 yr BP ( 4350 - 4200 cal yr BP). 


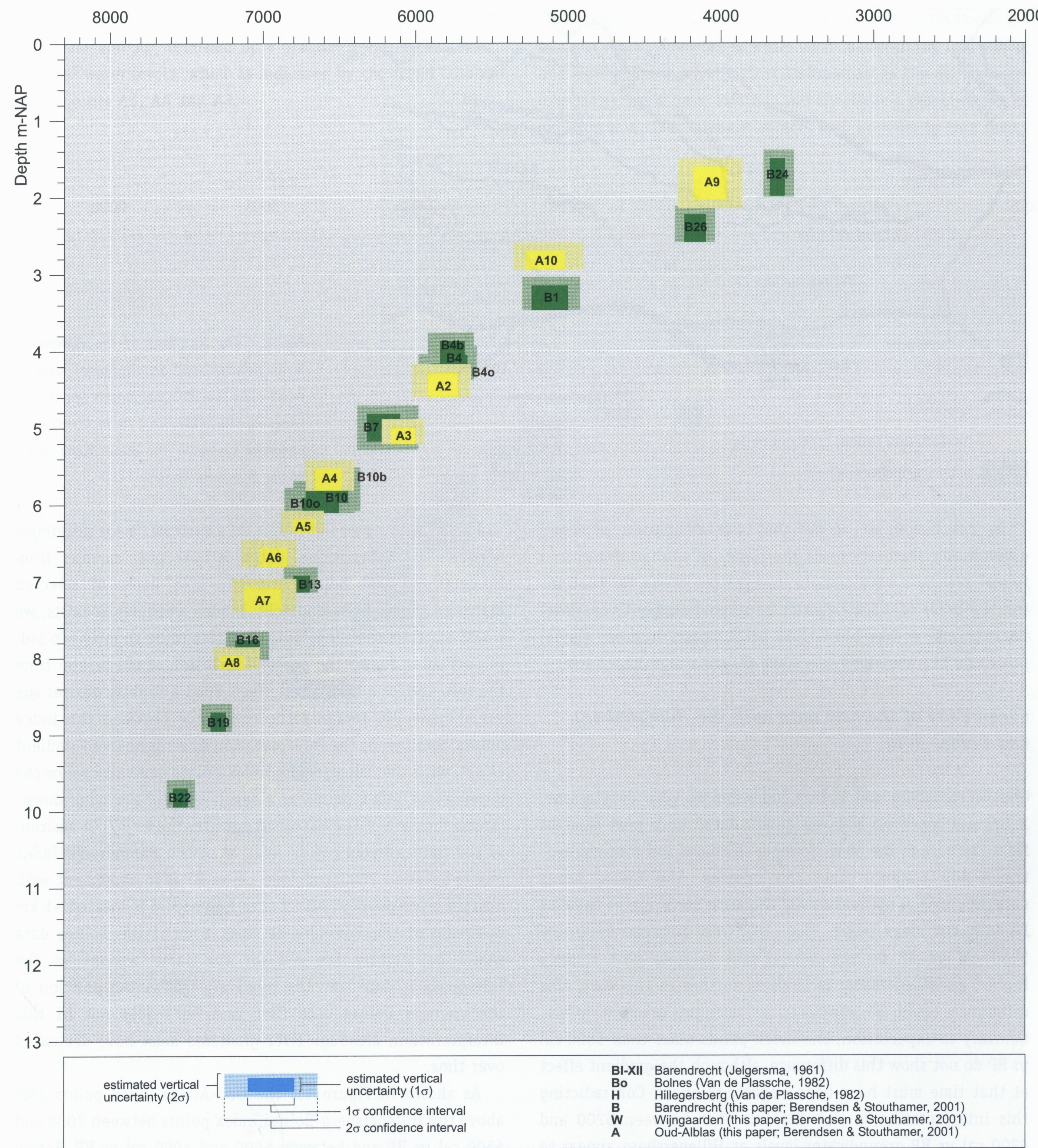

Fig. 7. Barendrecht groundwater-level index points (green) compared with Oud-Alblas groundwater-level index points (yellow).

difference between AMS (Oud-Alblas) and conventional dates (Wijngaarden), which is not evident from the Barendrecht data (Fig. 5). Moreover, after 5500 cal yr BP no age difference is observed between the Wijngaarden en Oud-Alblas data sets.

In any case, the data suggest varying floodbasin-water levels over short distances, possibly related to the avulsion that led to the formation of the Schaik channel belt. If fluctuating floodbasin-water levels in the Rhine-Meuse delta are indeed caused by avulsions, such fluctuations may be related to the average period of existence $(\sim 1100 \mathrm{cal} \mathrm{yr})$ of channel belts (Berendsen \& Stouthamer, 2001), or to the duration ( $500-600$ cal yr) of avulsion sequences (Stouthamer \& Berendsen, 2007). This gives a maximum order of magnitude of the duration of locally raised floodbasin-water levels due to avulsions. 




Fig. 8. The locations of the Zijderveld, Schoonrewoerd and Schaik fluvial systems relative to the Wijngaarden en Oud-Alblas sampling sites (see Fig. 1 for location). The Langerak system is the downstream reach of the Zijderveld system.

In conclusion, it seems that the evaluation of small groundwater fluctuations at the flanks of aeolian dunes in a fluvial area is a very complicated matter. Small fluctuations (on the order of $0.5 \mathrm{~m}$ ) cannot be related simply to sea-level fluctuations, as has been tried in the past. Instead, fluvial processes like avulsions may have played a significant role.

\section{Comparison of the new data with the Hillegersberg and Bolnes data}

The Hillegersberg and Bolnes index points (Van de Plassche, 1982) are based on conventionally dated bulk peat samples from the base of the peat. Younger rhizomes and rootlets were thoroughly removed from the samples. The index points generally plot at approximately the same elevation as the new Barendrecht index points (Fig. 10). Only between 6800 and 5500 cal yr BP do the Barendrecht samples plot slightly higher. As Hillegersberg is situated further to the west, this difference could be explained as a slight gradient effect. Contrary to expectation, the index points older than $6800 \mathrm{cal}$ yr BP do not show this difference, although the gradient effect at that time must have been slightly stronger. Contradicting this interpretation is also the fact that between 5200 and 4200 cal yr BP groundwater levels at Hillegersberg appear to be higher than at Barendrecht.

The new Barendrecht index points in.Figure 10 suggest an abrupt rise at $\sim 6700$ cal yr BP followed by a gradual convergence with the Hillegersberg index points forward in time. This difference in elevation of the Barendrecht and Hillegersberg index points between 6800 and $5500 \mathrm{cal}$ yr BP may also be related to an avulsion, but at present no detailed data are available for this area and that time interval.
Figure 10 gives no indication for a systematic age difference between the conventional dates of bulk peat samples from Hillegersberg and Bolnes and the AMS dates of selected macroremains from Barendrecht. If such a difference exists, we would expect the Hillegersberg samples to be slightly too old, in particular due to the possible inclusion of old carbon from the soil, and/or a hardwater effect. Such a slightly greater age would generally increase the difference between the index points, and favour the interpretation of a slight river-gradient effect, with the Hillegersberg index points generally below the Barendrecht index points as a result of a $\sim 4 \mathrm{~km}$ more downstream location of the Hillegersberg site. The high/old position of the Bolnes index points relative to the Barendrecht index points between 7600 and $7000 \mathrm{cal}$ yr BP is in agreement with a slight river-gradient effect (the Bolnes site is located $\sim 1 \mathrm{~km}$ upstream of the Barendrecht site), even if the Bolnes data would be slightly too old for the same reasons as the Hillegersberg data set. The relatively low/young position of the younger Bolnes data (Bo6 and Bo7) does not fit this interpretation, although river gradients must have decreased over time.

As shown in Figure 11, the Oud-Alblas index points plot above the Hillegersberg-Bolnes index points between 7000 and $6500 \mathrm{cal}$ yr BP and between 5500 and 4000 cal yr BP. Before $7000 \mathrm{cal}$ yr BP and between 6200 and $5500 \mathrm{cal}$ yr BP they are at the same elevation. If we attribute the relatively high position of the 0ud-Alblas index points between 5500 and $4000 \mathrm{cal}$ yr BP to the avulsions of the Zijderveld and Schoonrewoerd fluvial systems (as argued above), the distribution of the index points before 5500 cal yr BP can be taken to represent either (1) a river-gradient effect, with the general divergence backward in time of the Oud-Alblas and Hillegersberg index points indicating an increasing gradient, or (2) an earlier, 
undocumented avulsion that caused a steep rise in water levels at approximately $7000 \mathrm{cal}$ yr BP, indicated by the index points $\mathrm{A} 7$ and $\mathrm{A6}$, followed by a gradual lowering relative to regional water levels, which is indicated by the trend through index points $\mathrm{A} 5, \mathrm{~A} 4$ and $\mathrm{A} 3$.
The relatively low/young position of the index points A7 and A8 contradicts the 'river-gradient' interpretation. On the other hand, a slight difference in water levels between the Oud-Alblas and Hillegersberg sites (almost $15 \mathrm{~km}$ apart in the alongstream direction), must have existed, and therefore a combination of avulsion and river gradient effects may be valid in this case.



Fig. 9. Barendrecht (green) and Oud-Alblas (yellow) groundwater-level index points from this study, and Wijngaarden (purple) groundwater-level index points from Van Dijk et al. (1991). 


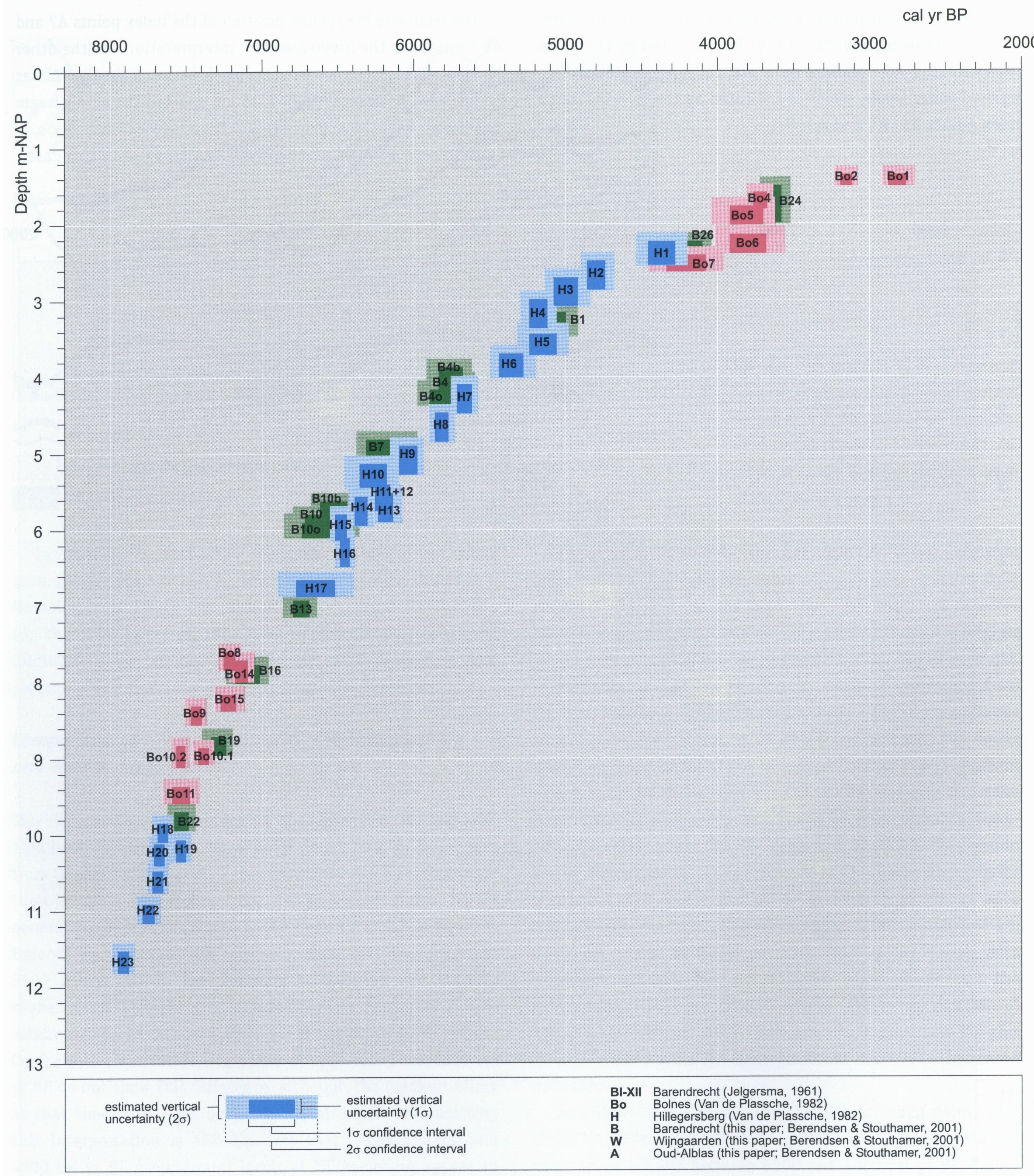

Fig. 10. Hillegersberg (blue) and Bolnes (pink) groundwater-level index points from Van de Plassche (1982) compared with the Barendrecht groundwater-level index points from this study (green).

\section{Discussion}

Van de Plassche $(1982,1995)$ suggested that the floodbasin effect significantly influenced regional water levels in the western Rhine-Meuse delta since $\sim 7500$ cal yr BP. The floodbasin effect involves lowering of mean high water (MHW) in a back-barrier lagoon relative to coastal MHW, as a result of friction and storage of the (limited) amount of water that can enter the lagoon through tidal inlets. The gradual development of a floodbasin effect is suggested by reconstructions of Holocene coastal evolution showing narrowing/closure of tidal inlets in the coast of Holland between 6500 and $5500 \mathrm{cal}$ yr 


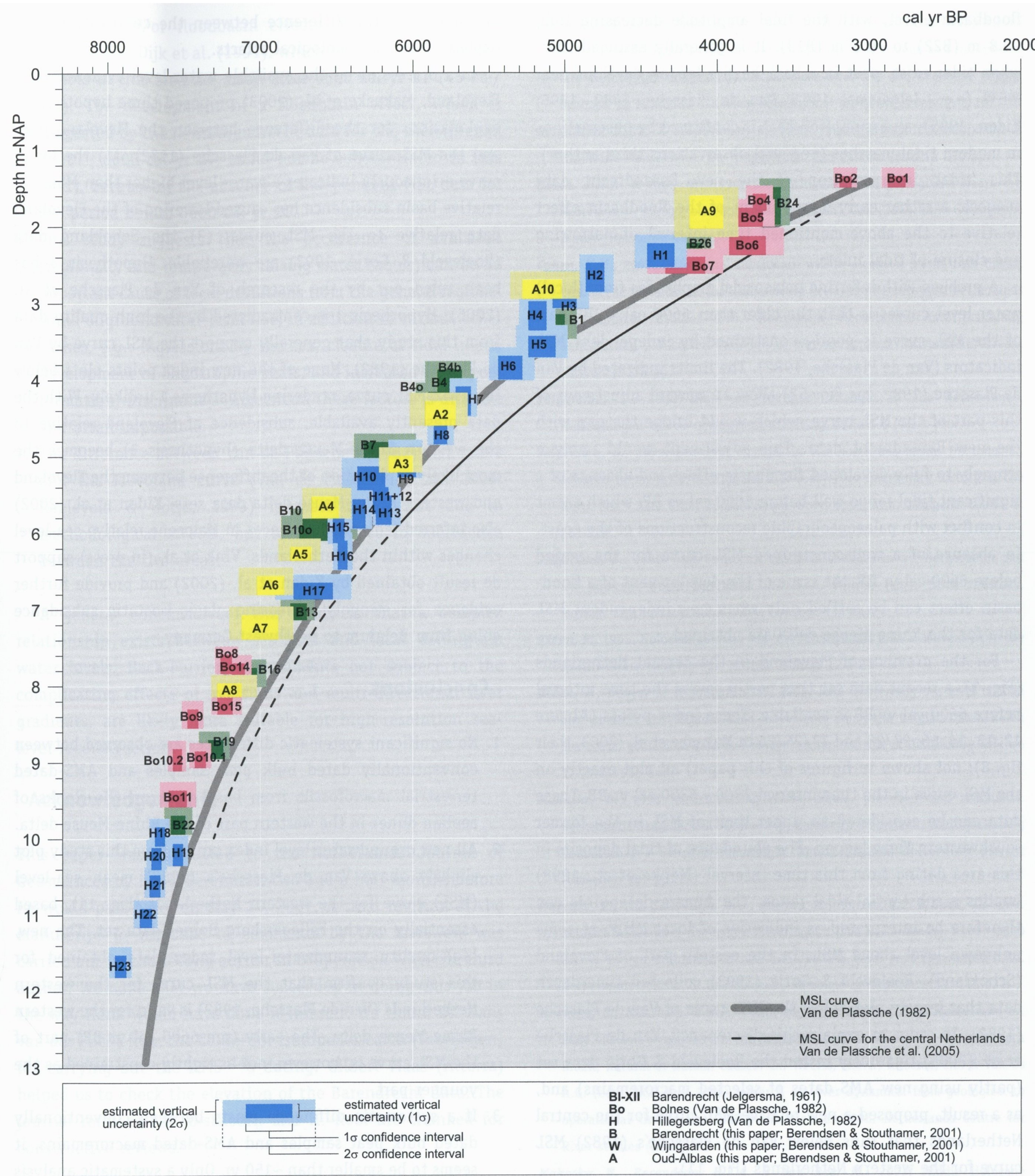

Fig. 11. Hillegersberg (blue) and Bolnes (pink) groundwater-level index points from Van de Plassche (1982) compared with the Barendrecht (green) and Oud-Alblas (yellow) groundwater-level index points from this study. Two previously published MSL curves (Van de Plassche, 1982; Van de Plassche et al., 2005) are also shown.

BP (Beets et al., 1992, 1994; Beets \& Van der Spek, 2000). To what extent do the new data from the western Rhine-Meuse delta support this notion of the development of a floodbasin effect since $\sim 7500 \mathrm{cal}$ yr BP?
If it is assumed that the MSL curve published by Van de Plassche (1982) is correct for the time interval $7500-6600 \mathrm{cal}$ $\mathrm{yr} \mathrm{BP}$, then the gradual convergence of the index points $\mathrm{B} 22$, B19, B16 and B13 (representing MHW) with the MSL curve (Fig. 11) could be taken to represent the development of a 
floodbasin effect, with the tidal amplitude decreasing from $\sim 0.8 \mathrm{~m}$ (B22) to $\sim 0.2 \mathrm{~m}$ (B13). It is generally assumed that, when tides exist, peat in a back-barrier lagoon develops near MHW (e.g., Jelgersma, 1961; Van de Plassche, 1982, 1995; Kiden, 1995), an assumption that is confirmed by observations in modern tidal marshes (personal observations third author). This 'tidal' interpretation of the new Barendrecht data suggests a rather early development of the floodbasin effect relative to the above-mentioned time interval of narrowing and closure of tidal inlets.

A problem with inferring palaeotidal amplitudes from (local) water-level curves is that the older than $6600 \mathrm{cal}$ yr BP part of the MSL curve is poorly constrained by independent MSL indicators (Van de Plassche, 1982). The limits indicated by Van de Plassche (1982, his Fig. 52) allow an upward adjustment of this part of the MSL curve, which would bridge the gap with the new Barendrecht data. This adjustment would imply a strongly to fully developed floodbasin effect and absence of a significant tidal range well before $6600 \mathrm{cal}$ yr BP, which seems in conflict with palaeogeographic reconstructions of the coast. In absence of a well-constrained MSL curve for the period before $6600 \mathrm{cal}$ yr BP, the issue of the development of a floodbasin effect can be settled only when new independent MSL data for the Rhine-Meuse delta are obtained.

For the province of Flevoland in the central Netherlands (Fig. 1), a recent data set that partly covers the time interval before $6600 \mathrm{cal}$ yr BP is available. These index points (Almere $12,13,14,15,27 / 28$ and 23/25/26 in Makaske et al. (2003, their fig. 8); not shown in figures of this paper) all plot exactly on the MSL curve in the time interval $7300-6300 \mathrm{cal}$ yr BP. These data can be considered an upper limit of MSL in the former southwestern Flevo lagoon. The abundance of tidal deposits in this area dating from this time interval (Menke et al., 1998) implies a substantial tidal range. The Almere datapoints can therefore be interpreted as indicative of local MHW, at some unknown level above MSL. In the eastern part of Flevoland (Schokland), Roeleveld \& Gotjé (1993) collected time-depth data that largely plot below the MSL curve of Van de Plassche (1982). In order to explain this discrepancy, Van de Plassche et al. (2005) rigorously tested the Roeleveld \& Gotjé data set (partly using new AMS dates of selected macroremains) and, as a result, proposed a new relative MSL curve for the central Netherlands that runs below Van de Plassche's (1982) MSL curve for the western Netherlands (Fig. 11).

Van de Plassche et al. (2005) left open the possibility that the difference between the two MSL curves is due to methodological effects (i.e., the difference between AMSdated macroremains and conventionally dated bulk samples). At that time, high-quality (AMS) index points were not available for the western Netherlands. This study provides new AMS index points from aeolian dunes in the western RhineMeuse delta, that also plot higher than AMS-dated index points from Flevoland (Van de Plassche et al., 2005). This indicates that the difference between the curves cannot be explained by methodological effects.

In a discussion of the available water-level evidence from Flevoland, Makaske et al. (2003) proposed three hypothetical explanations for the difference between the Flevoland data and the MSL curve of Van de Plassche (1982): (1) the latter curve erroneously indicates a water level higher than MSL, (2) relative basin subsidence has caused lowering of the Flevoland data relative to the MSL curve, (3) the Schokland data (Roeleveld \& Gotjé, 1993) are unreliable. Hypothesis 3 has been ruled out by the research of Van de Plassche et al. (2005). Hypothesis 1 is contradicted by the high-quality data from this study that generally support the MSL curve by Van de Plassche (1982). None of the new index points plots below the 1982-MSL curve, rendering hypothesis 1 unlikely. With the data presently available, subsidence of Flevoland relative to the western Rhine-Meuse delta (hypothesis 3) becomes the most likely explanation of the difference between the Flevoland and western Rhine-Meuse delta data sets. Kiden et al. (2002) also inferred regional differences in Holocene relative sea-level changes within the Netherlands. Vink et al. (in press) support de result obtained by Kiden et al. (2002) and provide further evidence for strongly increasing glacio-isostatic subsidence going from Belgium to northwest Germany.

\section{Conclusions}

1. No significant systematic differences are observed between conventionally dated bulk peat samples and AMS-dated terrestrial macrofossils from basal peat on the flanks of aeolian dunes in the western part of the Rhine-Meuse delta.

2. All new groundwater-level index points from this study plot slightly above Van de Plassche's (1982) mean sea-level (MSL) curve for the western Netherlands (Fig. 11), based essentially on the Hillegersberg-Bolnes data set. The new, high-quality groundwater-level index data obtained for this study confirm that the MSL curve for the western Netherlands (Van de Plassche, 1982) is valid for the western Rhine-Meuse delta. The early (pre-6600 cal yr BP) part of the MSL curve is, however, not as tightly constrained as the younger part.

3. If a systematic difference exists between conventionally dated bulk peat samples and AMS-dated macroremains, it seems to be smaller than 150 yr. Only a systematic analysis of conventional bulk dating and AMS dating on subsamples from the same sample can provide more information on this.

4. Depth selection of basal peat samples is less critical than previously thought, as long as the top of the palaeosoil in the underlying deposits is not included, and macroremains are selected from levels with indications for wet conditions (peat formation).

5. Differences between groundwater-level rise trends at individual aeolian dunes may be caused by differences in 
gradient and/or floodbasin effects. Results confirm the study of Van Dijk et al. (1991), which suggests that gradient effects in this area are small after $6600 \mathrm{cal}$ yr BP $(\leqslant 5 \mathrm{~cm} /$ $\mathrm{km})$. The development of a floodbasin effect, which is suggested by the new Barendrecht data for the time interval $7500-6600$ cal yr BP, could not be substantiated in this study, because of the absence of independent MSL data for the period before $6600 \mathrm{cal}$ yr BP.

6. This study suggests that the occurrence of avulsions (regionally and temporarily raising water tables) can be an important cause of local deviations from the general regional trend of groundwater-level rise, in addition to various other causes, e.g.: ingressions by the sea, closure of tidal inlets, development of oligotrophic peats, and increased wood peat formation. Discrimination between these factors is difficult and often impossible.

7. The difference between Van de Plassche's (1982) MSL curve and the Flevoland curve (Van de Plassche et al., 2005; Roeleveld \& Gotjé, 1993) is most likely not due to methodological effects, but to differences in subsidence between the two areas.

A general conclusion of this study is that a complex relationship exists between sea-level and local delta-plain water levels. Back-barrier environments not subject to the complicating effects of avulsions and multi-directional river gradients, are likely more suitable for high-resolution sealevel reconstruction.

\section{Acknowledgements}

This paper was submitted to the Netherlands Journal of Geosciences by Henk Berendsen two and a half months before he would pass away on May 14, 2007. A final revision of the manuscript in response to comments by the reviewers was carried out by the second author in cooperation with the third author. We hope that we have succeeded in doing this job in the way Henk would have done it himself. We thank Dr. Hans van der Plicht from the Center for Isotope Research (Groningen) for carrying out the AMS ${ }^{14} \mathrm{C}$ dating. Gilbert Maas (Alterra) helped us to check the elevation of the Barendrecht data. The journal referees T.N. Olsthoorn and H. Kooi are thanked for constructive reviews.

\section{References}

Beets, D.J., Van der Valk, L. \& Stive, M.J.F., 1992. Holocene evolution of the coast of Holland. Marine Geology 103: 423-443.

Beets, D.J., Van der Spek, A.J.F. \& Van der Valk, L., 1994. Holocene ontwikkeling van de Nederlandse kust. RGD rapport 40.016 - Projekt Kustgenese, Rijks Geologische Dienst (Haarlem): 53 pp.
Beets, D.J. \& Van der Spek, A.J.F., 2000. The Holocene evolution of the barrier and the back-barrier basins of Belgium and the Netherlands as a function of late Weichselian morphology, relative sea-level rise and sediment supply. Geologie en Mijnbouw / Netherlands Journal for Geosciences 79: 3-16.

Berendsen, H.J.A. \& Stouthamer, E., 2001. Palaeogeographic development of the Rhine-Meuse delta, the Netherlands. Van Gorcum (Assen): $250 \mathrm{pp}$.

Bosch, J.H.A. \& Kok, H., 1994. Toelichtingen bij de geologische kaart van Nederland $1: 50.000$; blad Gorinchem (Gorkum) West (38W). Rijks Geologische Dienst (Haarlem): $159 \mathrm{pp}$.

Cohen, K.M., 2003. Differential subsidence within a coastal prism, Late-Glacial - Holocene tectonics in the Rhine-Meuse delta, the Netherlands. Netherlands Geographical Studies 316, Koninklijk Nederlands Aardrijkskundig Genootschap / Faculteit Ruimtelijke Wetenschappen, Universiteit Utrecht (Utrecht): $176 \mathrm{pp}$

Jelgersma, S., 1961. Holocene sea-level changes in the Netherlands. Mededelingen van de Geologische Stichting, Serie C 6 (7): 1-100.

Jelgersma, S., 1979. Sea-level changes in the North Sea basin. In: Oele, E., Schüttenhelm, R.T.E. \& Wiggers, A.J. (eds): The Quaternary history of the North Sea - Acta Univ. Uppsala Symp. Univ. Upps. Ann. Quingent. Celebr. 2: 233-248.

Jelgersma, S., 1980. Late Caenozoic sea level changes in the Netherlands and the adjacent North Sea basin. In: N.-A. Mörner (ed.): Earth rheology, isostasy and eustacy. John Wiley, London: 435-447.

Kiden, $\boldsymbol{P}_{\mathbf{0}}, 1995$. Holocene relative sea-level change and crustal movement in the southwestern Netherlands. Marine Geology 124: 21 - 41.

Kiden, P., Denys, L. \& Johnston, P., 2002. Late Quaternary sea-level change and isostatic and tectonic land movements along the Belgian-Dutch North Sea coast: geological data and model results. Journal of Quaternary Science $17(5-6): 535-546$.

Makaske, B., 1998. Anastomosing rivers; forms, processes and sediments. Netherlands Geographical Studies 249, Koninklijk Nederlands Aardrijkskundig Genootschap / Faculteit Ruimtelijke Wetenschappen, Universiteit Utrecht (Utrecht): $287 \mathrm{pp}$.

Makaske, B., Van Smeerdijk, D.G., Peeters, H., Mulder, J.R. \& Spek, T., 2003. Relative water-level rise in the Flevo lagoon (the Netherlands), $5300-2300$ cal. yr BC: an evaluation of new and existing basal peat time-depth data. Netherlands Journal of Geosciences / Geologie en Mijnbouw 82: 115-131.

Makaske, B., Maathuis, B.H.P., Padovani, C.R., Stolker, C. \& Mosselman E., 2006. Recent avulsions on the Taquari megafan, Pantanal, south-western Brazil; natural or human causes? In: Weerts, H.J.T., Ritsema, I.L. \& Van Os A.G. (eds): NCR-days 2005; research on river dynamics: from geological to operational time scales. NCR-publication 29-2006, Netherlands Centre for River studies (Delft): 16-18.

Makaske, B., Berendsen, H.J.A. \& Van Ree, M., 2007. Middle Holocene avulsion-belt deposits in the central Rhine-Meuse delta, the Netherlands. Journal of Sedimentary Research 77: 110-123.

Menke, U., Van de Laar, E. \& Lenselink, G., 1998. De geologie en bodem van Zuidelijk Flevoland. Flevobericht 415, Rijkswaterstaat Directie IJsselmeergebied (Lelystad): $93 \mathrm{pp}$.

Roep, Th. B. \& Beets, D.J., 1988. Sea level rise and paleotidal levels from sedimentary structures in the coastal barriers in the western Netherlands since 5600 BP. Geologie en Mijnbouw 67: 53-61. 
Roeleveld, W. \& Gotjê, W., 1993. Holocene waterspiegelontwikkeling in de Noordoostpolder in relatie tot zeespiegelbewegingen en kustontwikkeling. In: Gotjé, W.: De Holocene laagveenontwikkeling in de randzone van de Nederlandse kustvlakte (Noordoostpolder). Ph.D. thesis, Vrije Universiteit (Amsterdam): 76-86.

Stouthamer, E. \& Berendsen, H.J.A., 2007. Avulsion: the relative roles of autogenic and allogenic processes. Sedimentary Geology 198: 309-325.

Streif, H., 1971. Stratigraphie und Faziesentwicklung im Küstengebiet von Woltzeten in Ostfriesland. Beihefte Geologisches Jahrbuch 119: 58 pp.

Streif, H., 1972. The results of stratigraphical and facial investigations in the coastal Holocene of Woltzeten/0stfriesland, Germany. Geologiska Föreningen i Stockholm Förhandlingar 94: 281-299.

Stuiver, M. \& Van der Plicht, J. (eds), (1998). INTCAL98: Calibration Issue. Radiocarbon 40 (3): 1041-1081.

Törnqvist, T.E. \& Bierkens, M.F.P., 1994. How smooth should curves be for calibration of radiocarbon ages ? Radiocarbon 36: 11-26.

Törnqvist, T.E., De Jong, A.F.M., Oosterbaan, W.A. \& Van der Borg, K., 1992. Accurate dating of organic deposits by AMS ${ }^{14} \mathrm{C}$ measurement of macrofossils. Radiocarbon 34: 566-577.

Törnqvist, T.E., Van Ree, M.H.M., Van 't Veer, R. \& Van Geel, B., 1998. Improving methodology for high-resolution reconstruction of sea-level rise and neotectonics by paleoecological analysis and AMS ${ }^{14} \mathrm{C}$ dating of basal peats. Quaternary Research 49: 72-85.

Van de Plassche, 0., 1980. Compaction and other sources of error in obtaining sea-level data: some results and consequences. Eiszeitalter und Gegenwart 30: $171-181$

Van de Plassche, 0., 1982. Sea-level change and water-level movements in the Netherlands during the Holocene. Mededelingen Rijks Geologische Dienst 36: 1-93.

Van de Plassche, 0., 1995. Evolution of the intra-coastal tidal range in the Rhine-Meuse delta and Flevo Lagoon, 5700 - 3000 yrs cal B.C. Marine Geology 124: 113-128.

Van de Plassche, O., Bohncke, S.J.P., Makaske, B. \& Van der Plicht, J., 2005. Water-level changes in the Flevo area, central Netherlands (5300 - 1500 BC): implications for relative mean sea-level rise in the western Netherlands. Quaternary International 133-134: 77-93.

Van Dijk, G.J., Berendsen, H.J.A. \& Roeleveld, W., 1991. Holocene water level development in the Netherlands' river area; implications for sea-level reconstruction. Geologie en Mijnbouw 70: 311-326.

Verbraeck, A., 1974. The genesis and age of the riverdunes (donken) in the Alblasserwaard. Mededelingen Rijks Geologische Dienst, Nieuwe Serie 25: 1-8.

Vink, A., Steffen, H., Reinhardt, L. \& Kaufmann, G., in press. Holocene relative sea-level change, isostatic subsidence and the radial viscosity structure of the mantle of northwest Europe (Belgium, the Netherlands, Germany, southern North Sea). Quaternary Science Reviews, doi:10.1016/ j.quascirev.2007.07.014. 